\title{
Postbiotics as a Safe Alternative to Live Probiotic Bacteria in the Food and Pharmaceutical Industries
}

\author{
Aziz Homayouni-rad ${ }^{1}$, Leili Aghebati-Maleki ${ }^{2}$, Hossein Samadi-Kafii ${ }^{3}$, Amin Abbasi $^{4}$, Nader Khani ${ }^{5}$ \\ 1.Professor, Department of Food Science and Technology, Faculty of Nutrition \& Food Sciences, Tabriz University of Medical \\ Sciences, Tabriz, Iran. ORCID ID: 0000-0001-6766-0108. \\ 2.Assistant professor, Immunology Research Center, Department of Immunology, Faculty of Medicine, Tabriz University of \\ Medical Sciences, Tabriz, Iran. ORCID ID: 0000-0002-0044-5961. \\ 3.Assistant professor, Drug Applied Research Center, Department of Microbiology, Faculty of Medicine, Tabriz University of \\ Medical Sciences, Tabriz, Iran. ORCID ID: 0000-0001-6026-8795. \\ 4.MSc Student, Student Research Committee, Faculty of Nutrition and Food Sciences, Tabriz University of Medical Sciences, \\ Tabriz, Iran. (Corresponding author), Tel: +98-4133854658, Email: aminabasi.tbz.med.ac@ gmail.com. ORCID ID: 0000-0001- \\ 5957-0540. \\ 5. MSc Student, Department of Food Science and Technology, Faculty of Nutrition \& Food Sciences, Tabriz University of \\ Medical Sciences, Tabriz, Iran. ORCID ID: 0000-0001-8294-8708.
}

\section{ABSTRACT}

Background and Aim: Food is the fundamental need of human life and has nutrients that support growth and health. Gastrointestinal tract microbiota includes beneficial microorganisms which have therapeutic effects and are known as probiotics. The studies on appropriate probiotic strains have led to the separation and identification of specific metabolic byproducts of probiotics known as postbiotics.

Materials and Methods In this review study, relevant data were collected by searching for the keywords of "probiotics, postbiotics, immune system, bioactivity, disease, health improvement, food and pharmaceutical industries" in the Web of Science, PubMed, Medline and Scopus databases. All articles related to experimental studies were included in the study and articles without full text were excluded.

Results: The probiotics must maintain their survival against inappropriate growth conditions of the processing, storage, distribution, preparation, and digestive system so that they can exert their beneficial effects on health. Conversely, probiotic metabolites can successfully overcome these unfavorable conditions and maybe a good alternative to probiotics. Considering their specific chemical structure, safety, long shelf-life, and the fact that they contain various signaling molecules, postbiotics may have anti-inflammatory, immunomodulatory, antihypertensive, inhibitory effect on abnormal cell proliferation, and antioxidant activities.

Conclusions: Postbiotics can mimic the fundamental and clinical role of probiotics, and due to their unique characteristics, they can be used in a delivery system (pharmaceutical/functional foods) to achieve health-promotion objectives and also prevention, and treatment of diseases.

Keywords: Postbiotic, Probiotic, Functional foods, Immune system, Health promotion Received: Aug 26, $2019 \quad$ Accepted: April 10, 2021

How to cite the article: Aziz Homayouni-rad, Leili Aghebati-Maleki, Hossein Samadi-Kafil, Amin Abbasi, Nader Khani.Postbiotics as a safe alternative to live probiotic bacteria in the food and pharmaceutical industries.SJKU 2021;26(4):132-157.

Copyright () 2018 the Author (s). Published by Kurdistan University of Medical Sciences. This is an open access article distributed under the terms of the Creative Commons Attribution-Non Commercial License 4.0 (CCBYNC), where it is permissible to download, share, remix, transform, and buildup the work provided it is properly cited. The work cannot be used commercially without permission from the journal 


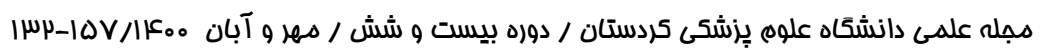

\section{يستبيوتيكها به عنوان جايكزين ايمن باكترىهاى زنده يروبيوتيك درصنايعغذايى و}

\section{دارويى}

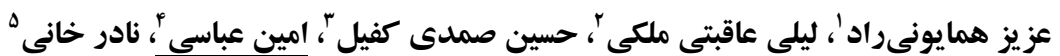

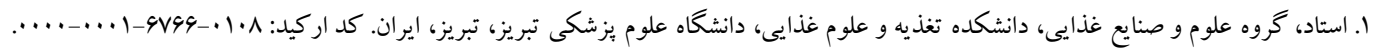

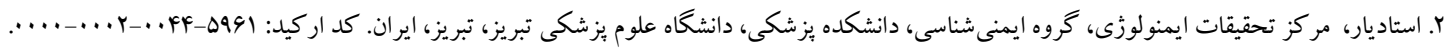

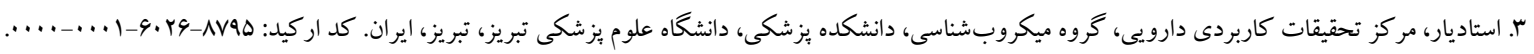

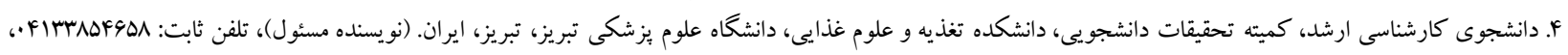

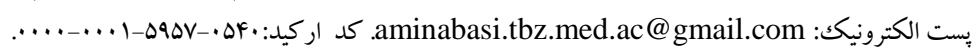

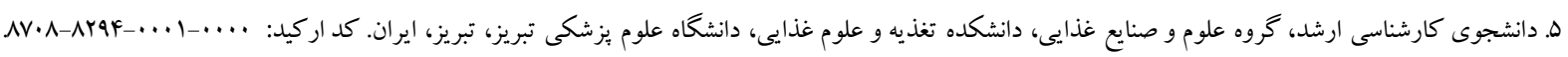

\section{جָكيله}

زمينه و هدف: غذا ضرورت اساسى حيات انسان است و مواد مغذى لازم براى رشد و سلامتى را مهيا مى كند. ميكروبيوتـاى دستگاه

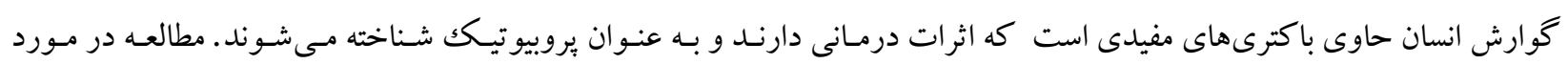

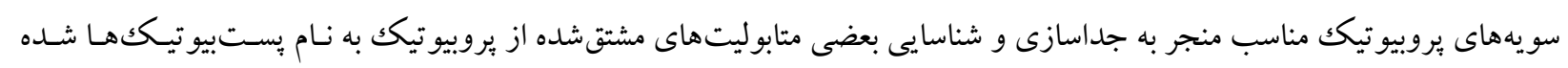

مواد و روش ها: در اين مطالعه مرورى دادههاى مربوطه با جستجوى كليد وازههاى "يروبيو تيك، بستبيوتيك، سيستم ايمنى، زيست فعالى، بيمارى، بهبود سلامت، صنايع غذايى و دارويى" در بايگاههاى اطلاعاتى وب آو ساينس، باب مد، مدلاين و اسكايوس كرد آورى شده است. تمامى مقالات مرتبط با مطالعات تجربى وارد مطالعه شده و مقالاتى كه حاوى متن كامل نبودند از مطالعه خارج

شدند.

يافته ها: باكترىهاى يروبيو تيك بايد در بر ابر شرايط نامناسب رشد مراحل فر آورى، نكهدارى، توزيع، آماده سازى و دستخاه گحوارش زنده مانى خود را حفظ كنند تا بتواند اثرات سلامتى بخش خود را ايفا كنند؛ درحالى كه متابوليتهاى آنها (يستبيو تيككها) به خوبى بر اين شر ايط نامساعد فائق آمده و ممكن است جايخزين خوبى براى بروبيوتيككها باشند . يستبيو تيككها با توجه بـه سـاختار شـيميايى

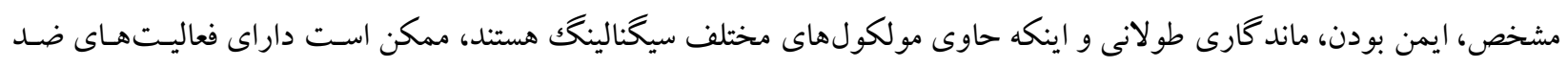
التهابى، تعديل كنندكى سيستم ايمنى و فشارخون، متوقف ساختن تكثير سلولى غير طبيعى و آنتى اكسيدانى باشند. نتيجه كيرى : يستبيو تيك ها تو انايى ايفاى نقش بالينى يروبيو تيككها را داشته و با توجه به ويثز كىهاى منحصر به فرد خود مى توانند در يكك سيستم تحويل (دارويى/ غذاهاى فراسودمند) جهت نيل به اهداف سلامتى بخش، بيشخيرى و درمان بيمارى ها مـورد استفاده قـرار بـ

كلمات كليلى: يستبيو تيكك، يروبيو تيك، غذاهاى فراسودمند، سيستم ايمنى، سلامت بخش

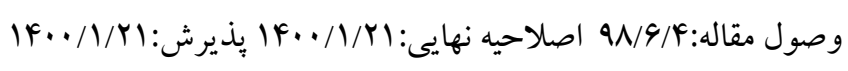


بدن را كه عامل تأثيرات سلامتى بخش سـلولهـاى باكتريـيى مفيد روده هستند، ارائه مى كنند( • (1 I). قابل تأمل اسـت كـه جنين مكانيسم هايى به وضعيت زنده بـودن بـاكترى هـا بسـتخى

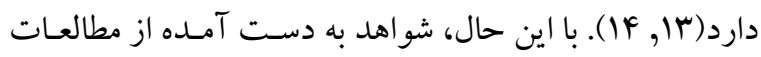
اخير نشان مىدهد كه زنده ماندن باكترىها بـر اي دستيابى بـهـ

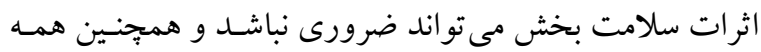
مكانيسمها و اثرات بالينى به طور مستقيم در ارتباط با باكترى هاى زنده مطرح نباشند. در اين رابطه تر كيبات زيستى مشـتق -

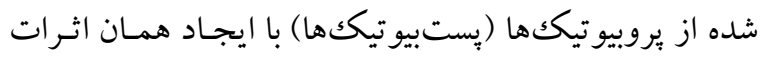

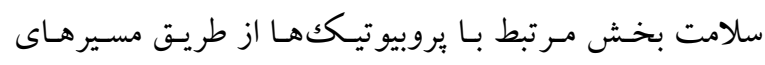

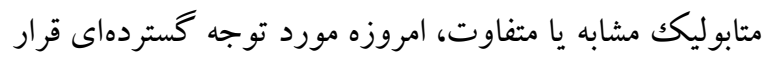

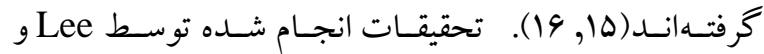

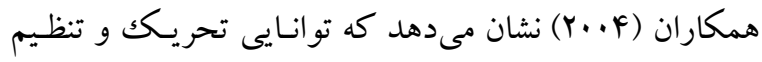
سيستم ايمنى بـدن توسط جهار فراكسيون بيفيلـ و باكتريوم

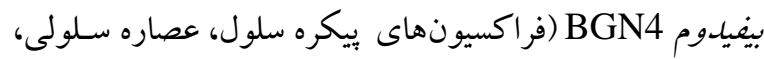
ديواره سلولى خالص و سـويرناتانت كشـت سـلولى) متفـاوت بوده و هر كدام از آن ها الكوهاى مختلفى درجريان واكسنش هـاى ايمنسى دارنــ(IV). عـلاوه بــر ايـن، فراكسيون عصـاره

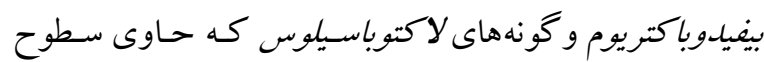
بالايى از كربوهيدراتهاى ميكروبى هستند، داراى فعاليتهاى

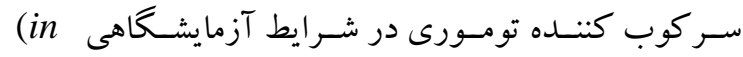
vitro) از ديدگاه بالينى نيز نتايج بهدست آمده از مطالعات بيشبالينى (Clinical) و بيـانكر ايـن هستيند كـه (Pre-clinical) برخى يروبيو تيككهاى مورد استفاده در مكمل هاى دارويسى يـا

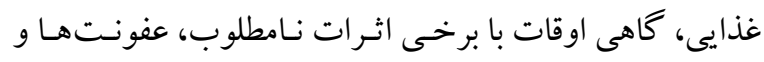
مسائل ايمنى همر اه هستند. از جمله اين موارد مى توان به انتقال

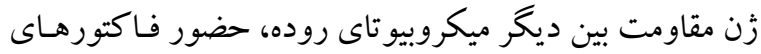

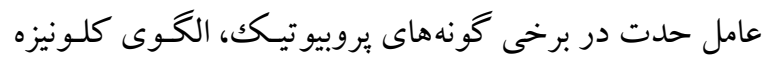

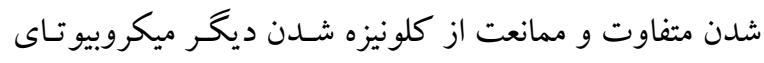

\section{مقدمه}

غذا نقش مهمى در زندگى داشته و مواد مغذى لازم براى رشد

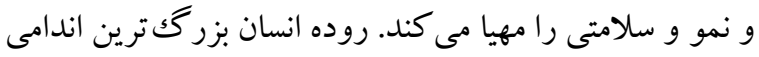
است كه در تعديل سيستم ايمنسى بـدن نقـش دارد كـه حساوى

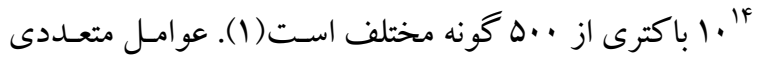

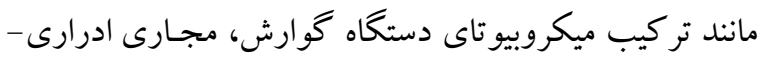
تناسلى و شير مادر، وضعيت تولد (طبيعى، سزارين)، شيوههاى

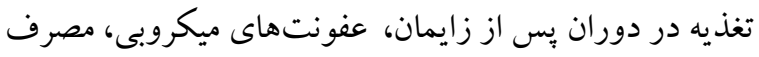
طيـف گسـتردهاى از آنتسىبيوتيـكهــا، رزيـم غــذايى بسـيار

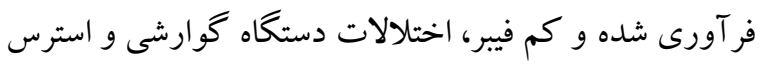

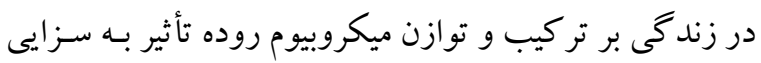
دارند. هر يكك از اين عوامل به نوبه خود مى تو انند نقشى مـؤثر در ايجاد اختلال يا برقرارى عملكرد مناسب و سلامت دستخاه

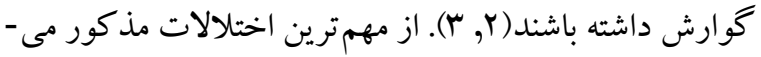
توان به ديس بيوزيس (Dysbiosis) اشاره كـرد كـه بـه معنى

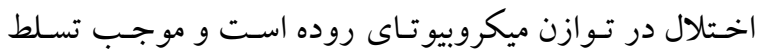
باكترىهاى بيمارىزا در محيط روده ميزبان مىشـود. مصرف

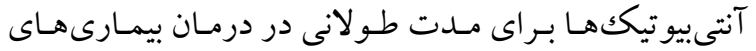

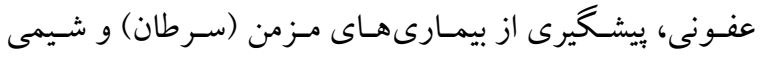
درمانى را مىتوان از عاملين اصلى ديسبيوزيس نام برد( (F, ه). يوبيوزيس (Eubiosis) نيز وضعيتى در مقابل ديسيسيوزيس

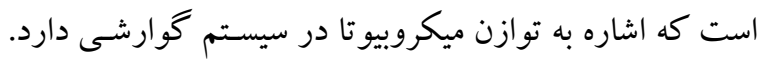

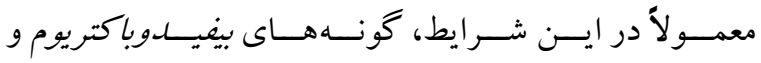
لاكتوياسيل ها غالب بوده و اثرات سلامت بخشى از خود بـروز مىدهند(4). براى غلبه بر عدم تعـادل در ميكروبيوتساى روده و

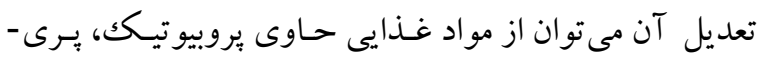

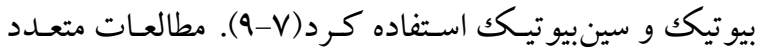

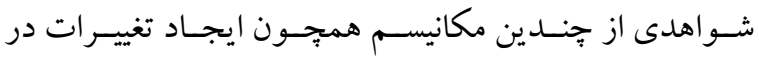

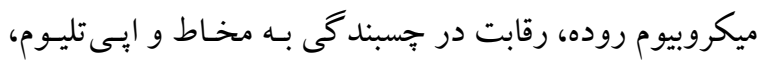
بهبود عملكرد يوشش دفاعى ايى تليال و تعـديل سيستم ايمنى رونى 
در اين مطالعه مرورى ساده براى شناسايى مطالعات انجـامشـده

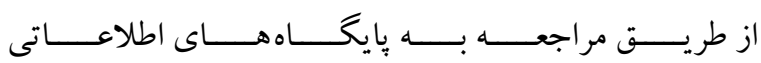
و Scopus ،PubMed/Medline ،Web of Science نسبت بـه جمـع آورى مطالعـات مـرتبط از Google Scholar

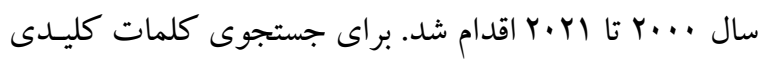
مربسوط بـه يسـت بيو تيـك شـامل Biogenic Metabiotic، ‘Pseudoprobiotic ،Abiotic ،Ghost-probiotic Paraprobiotic (OR) اسـتفاده شـــ و همجتـــن بـراى بخـش دوم از كلمـات

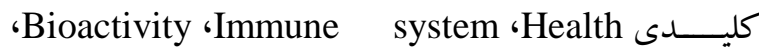
'Identification methods 'Extraction methods Food ،Safety (OR) اسـتفاده شـد. بـراى اتصـال دو بخـش نيـز از كلمـه (او)" براى جستجوى نهايى استفاده شد. معيارهاى ورود به (AND) شرح ذيل بودند، مقالاتى كه به بررسى تأثير مكمل يا محصول دارويى يا غذايى يسـت بيو تيـك بـر وضسعيت سـلامت ميزبـان، يشيشيرى يا بهبود روند بيمارى برداخته بودند؛ مقالاتى كه به بررسى روش هـاى استخراج و شناسـايى يسـتبيوتيككهـا. يرداخته بودند؛ مقالاتى كه به متن كامل آنها دسترسى وجـود داشت؛ مطالعات آزمايشگاهى و كار آزمايى بالينى و مطالعاتى كه روى نمونههاى انسانى انجام شده بودند. معيارهـاى خـروج نيز شامل موارد ذيل بودند، مقالاتى كه تنهـا جـكيـده آنهـا در

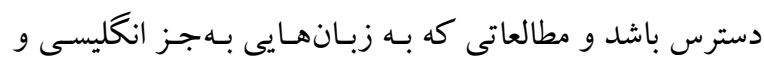
فارسى نوشته شده باشند. در نهايت تعداد •11 مقاله يافت شـد كه تعداد س Vقاله از آنها به علت اين كه مرتبط با هدف مقاله

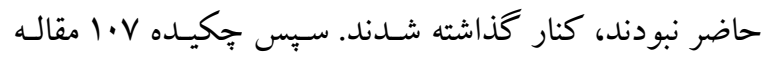
مرتبط، تهيه و مورد مطالعه و بررسى قـرار گرفتنـد. در نهايـت تنها ·r مقاله كه در راستاى اهداف و معيارهـاى ورود مطالعـه حاضر بودند، مورد بررسى قرار كر فتند.

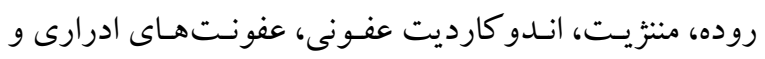
باكتريمى به ويزه در نوزادان، افرادى كه تحت درمان با آنتى بيوتيكك بوده و عملكرد سيستم ايمنسى ضسعيفى دارنـد، اشـاره كرد(19-19). همجينين از لحاظ تكنولوزيكى، حفظ زندهمانى يروبيو تيككها در مراحل مختلـف توليـد، نخهــارى و توزيـع، انتخاب حامل هاى مناسب، تلاش براى استانداردسـازى مقـدار بهينه يروبيو تيككها با توجه به فعاليت هـاى مختلـف متـابوليكى هر كدام و هزينههـاى لازم بـراى دسـيابى بـهـ ايسن اهـداف در جهت حصول اثرات سلامت بخش در ميزبـان، همـواره مـورد دغدغه بثزوهشگران و توليد كنند كان بوده و در صـدد كاهش هزينها ها وارتقا ايمنى محصولات و وضعيت سـامتى مصرف

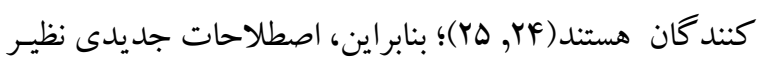

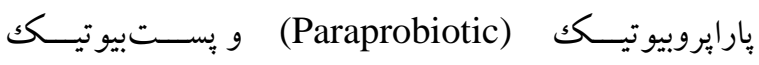
به وجود آمدهاند كه مفهوم بىنيازى از زنـده (Postbiotic) مانى باكترى هاى بروبيو تيك براى ايجاد اثرات سلامتى بخـش آنها را توضيح دهند. على رغم اثربخش بودن بروبيو تيككهـا، يستبيو تيككهاى حاصل از آنها ممكن است با كـاهش خطر ابتلا به باكتريمى(Bacteremia)، ايجاد عفونت و يـا افزايش ياسخ التهابى كه بـراى برخهى از مصـرف كنــد كان بـا سيسـتم ايمنى نامتعادل يا ضعيف نشان داده شده، دار ایى مزايـاى ايمنى بر بروبيو تيككهـا باشـند(Y), YV). در مطالعـات قبلى صسورت كرفته تنها تعداد اندكى از يافته هاى مربوط به بستبيو تيككهـا

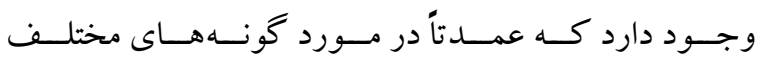
لاكتوباسيلوس بحـث شـده اسـت. از ايسن رو، در ايسن بررسى لـ

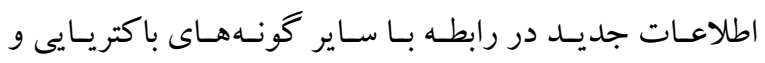
مخمرى گزارش شده به عنـوان منبـع بسـت بيوتيـك، خـواص بيولوزيكى، اثرات سلامتى بخش و مكانيسمهاى بـالقوه آنهـا در فعاليتهاى مختلف زيستى گز ارش شده است.

يافتهها

مواد و روشها - (- موشا تعريف بِتبيو تيككها:

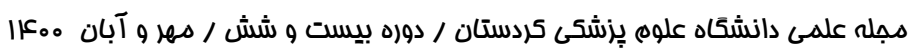


(Short-chain fatty acids)

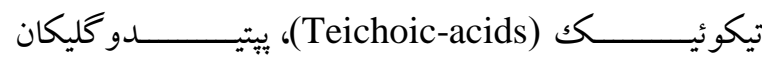

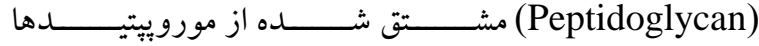
(Muropeptides) سطحى سلول، ويتـامينهـا، يُاسـمالوزنهـا (Plasmalogen) اسيدهاى آلى نمونه هايى از يستبيو تيككهاى محلول توليـدى

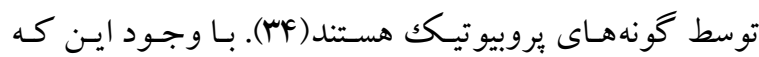

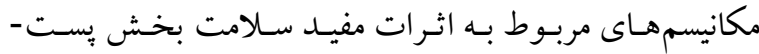

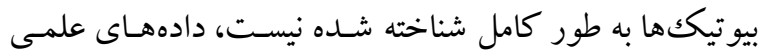

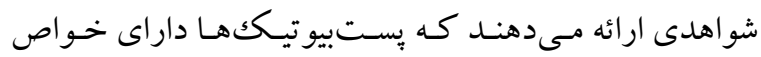

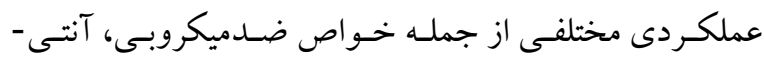

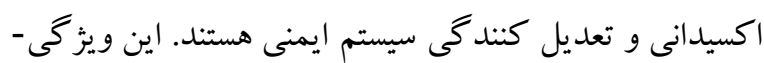
ها مى توانند به طور مثبت در هومئوستازيس (Homeostasis)

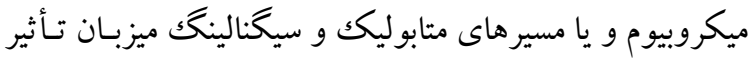

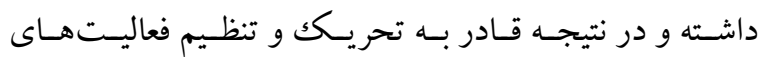

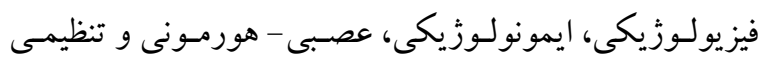
ميزبان خو اهند بـود(ها). امـروزه منـابع علمى در دسترس در

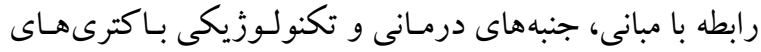
زنده (يروبيو تيككها)) وجود دارد و در اكثر اين منابع بر سـلول -

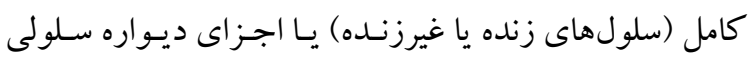

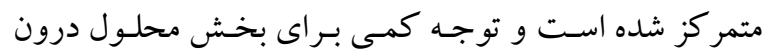

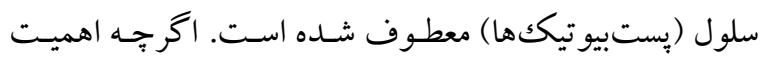
يست بيو تيككها نسبتاً ناديده گرفته شده است؛ اما مطالعاتى كـه اثرات مفيد سلامت بخش آنها را بررسى مسى كنتـد، در حسال افزايش است(4) (شكل ()).
يست بيو تيككها، تر كيبات محلول شامل سلول غيرزنده، ديواره سلولى، سلول ليز شده، فراكسيون، ترشحات، اجزاو متابوليت هاى سلولى مىباشند كه از باكترىهاى بروبيو تيكك بـه دسـت

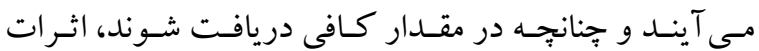
سلامت بخش از خود در ميزبان بر جاى مى كذارنسد. همجنسين يست بيو تيككها اثرات سلامت بخش متابوليتهاى باكترىهاى

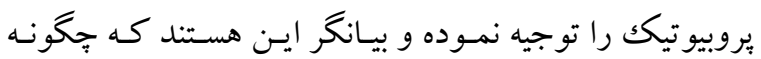
باكترىهاى بروبيو تيكك بعد عبور از سـدهـاى دفـاعى دستّكاه

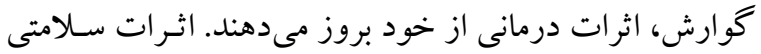
بخش ميكروبيوم روده از دو طريق اصلى تأمين مى شود، مسير

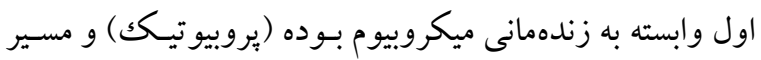
ديخر وابسته به محصولات غير زنده ميكروبيوم (يستبيو تيكك)

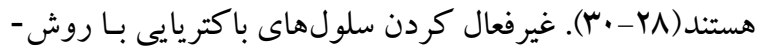
هاى فيزيكى (شكستن مكانيكى، تيمار حرارتى، تـابش اشعه

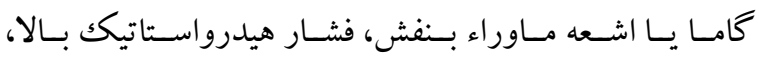
خشك كردن انجمادى، فراصوت) و يـا روشهـاى غيرفعـال-

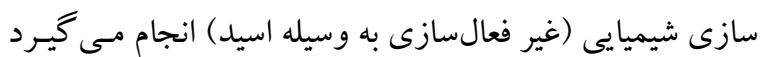
كه مىتواند ساختارهاى سلولى يا عملكرد فيزيولوزيكى آنهـا را تغيير دهد. از اين رو بعد از اعمال ايـن روشهـا، بـاكترىهـا

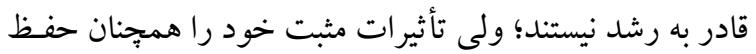

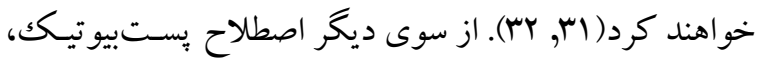

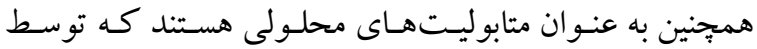

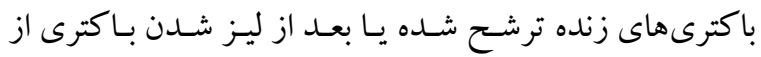

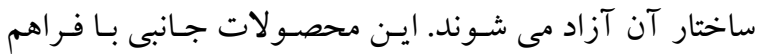

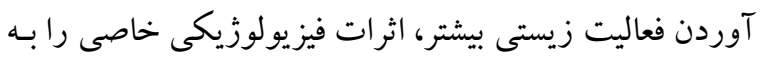

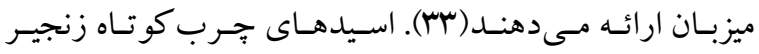




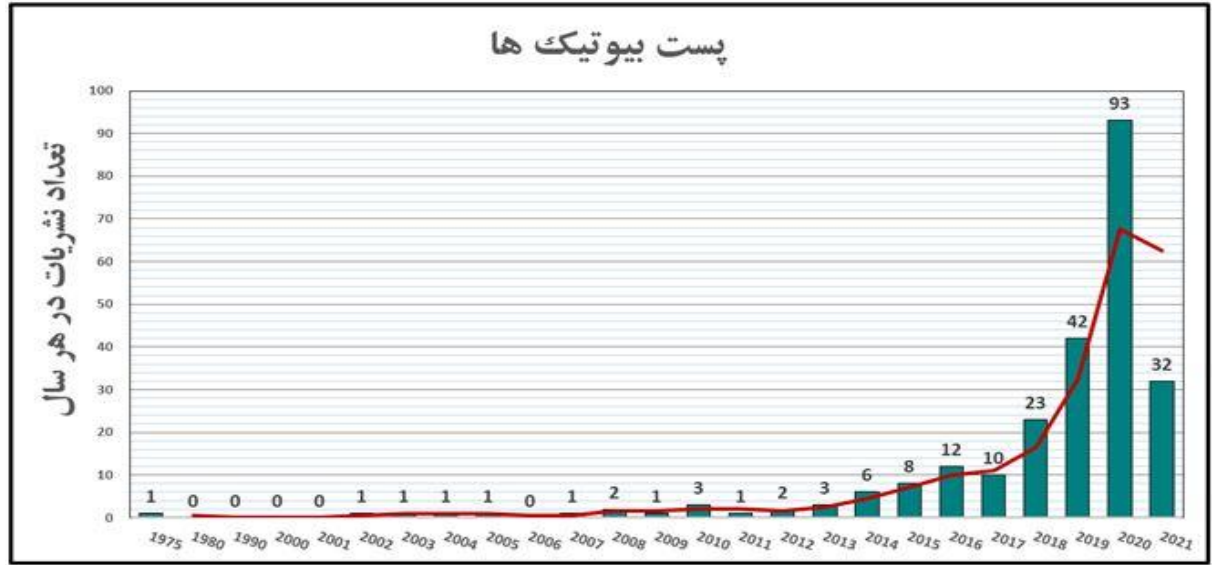

شكل ا. روند روبه رشد هزوهشهاى صورت كرفته در سالهاى اخير با محوريت هستبيوتيكها (بر كرفته از يايكاه اطلاعاتى Pubmed).

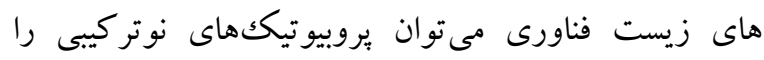
طبقهبندى بست بيو تيككها : طراحى كرد كه قادر به ارائه خواص مفيد مانند توليد باكترىهايى كه در روده حضور دارند، مواد غذايى مورد نياز متابوليتهاى زيستفعال خاصى باشند. يستبيوتيكها بر بر خودشان را از محيط روده ميزبان تأمين مى كنند. اين باكترىها اساس نوع و تركيب شيميايى به انواع ليبيدى (بوتيرات در طول جرخه زندكى خود متابوليتهايى با وزن مولكولى (Butyrate)، بروبيونات (Propionate)، دى متيل استيل يايين توليد مى كنند كه اين تركيبات نقش مهمى در تنظيم مشتق شده از پاسمالوزن)، يروتئينى (مانند لاكتوسيين رشد و نمو، توليد مثل، رشد ديخر ارگانيسمهاى مفيد، (Lactocepin) غنى از كالاكتوز و اسيد تيكوئيك)، ويتامينى(ويتامينهاى كروه B)، اسيدهاى آلى (اسيد بروبيونيك و ب- فنيل لاكتيك اسيد) و مولكولهاى بيجيده تر مانند بيتيدو كليكان مشتقشده از موروييتيدها، اسيد لييوتيكوئيد (Lipoteichoic acid) يا بر اساس عملكرد فيزيولوزيكى آنها طبقه بندى مىشوند(ه)

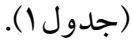
ارتباطات سلولى و محافظت در مقابل عوامل استرسزا ايفا مى كنند(rV). برخى از اين متابوليتهاى محلول توسط باكترىهاى زنده ترشح شده يا يس از ليز شدن باكترىها در محيط روده ميزبان آزاد مىشوند و با ارائه تغييرات فيزيولوزيكى با اصلاح فرآيندهاى سلولى و مسيرهاى متابوليكى در ميزبان، اثرات فيزيولوزيك خاصى را به وجود

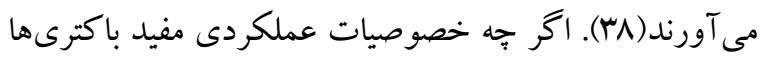
متفاوت از يكديكر هستند، از نظر تكنيكى با استفاده از روش -

جدول ا. مطالعات انجامشده در مورد اثرات زيست فعالى يستبيوتيكهها در مدل in vivo in vitro.

\begin{tabular}{|c|c|c|c|c|c|c|}
\hline منبع & شناسايى و روش & زيست فعالى و & نوع مطالعه & مشتبيو تيكى & باكترى & مطالعه/سال \\
\hline (f.) & علدم وجود اطلاعات كافى & تعديل سيستم & ماكروفازهاى رده & سلو سلى ديواره & لوكونه هاى بيفيلوباكتريوم، لاكتوباسيلوس /سيدفيلوس، & $\begin{array}{l}\text { Tejada- } \\
\text { Simon and } \\
\text { Pestka } \\
(1999)\end{array}$ \\
\hline
\end{tabular}




$$
\begin{aligned}
& \text { لاكتوياسيلوس دلبروكى زير سيتويلاسمى } \\
& \text { كونه بولكاريكوس، } \\
& \text { لاكتوباسيلوس هلويتيكوس، } \\
& \text { لاكتوياسيلوس روترى و } \\
& \text { استريتوكوكوس ترموفيلوس روترك }
\end{aligned}
$$

\begin{tabular}{|c|c|c|c|c|c|c|}
\hline (F) & اطلاعات كافى & تعديل سيستم & $\begin{array}{c}\text { رده سلولى سرلى كولون } \\
\text { (Caco-2 } \\
\text { cells) }\end{array}$ & فيتوزول & 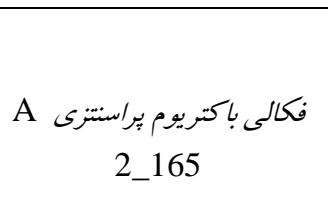 & $\begin{array}{l}\text { Sokol et al. } \\
\qquad(\ulcorner\cdot \wedge)\end{array}$ \\
\hline (IV) & اطلاعات كافى & تعديل سيستم & $\begin{array}{l}\text { ماكروفازهاى رده } \\
\text { RAW264.7 }\end{array}$ & سوير دارهاتانت سلولى، & بيفيدوباكتريوم بيفيدوم 4 & $\begin{array}{l}\text { Lee et al. } \\
\quad(r \ldots r)\end{array}$ \\
\hline (FY) & $\begin{array}{c}\text { ستون } \\
\text { Octyl- } \\
\text { Sepharose } \\
\text { CL-4B } \\
\end{array}$ & تعديل سيستم & $\begin{array}{c}\text { رده سلولى } 2 \text { سانى كولون } \\
\text { (HT-29 cells) }\end{array}$ & 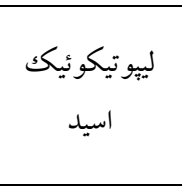 & 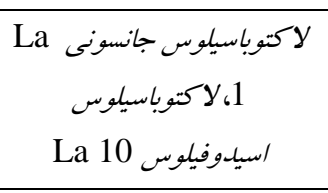 & $\begin{array}{l}\text { Vidal et al. } \\
\quad(r \cdot . r)\end{array}$ \\
\hline$(F+)$ & اطلاعات كافى & تعديل سيستم & 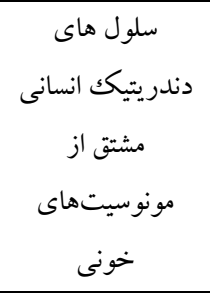 & سويرناتانت & لاكتوياسيلوس پاراكازئى & $\begin{array}{l}\text { Mileti, } \\
\text { Matteoli, } \\
\text { Iliev, and } \\
\text { Rescigno } \\
\quad(\text { (.ฯ৭) }\end{array}$ \\
\hline$(F \psi)$ & اطلاعات كافى وجود & ضد التهابى & 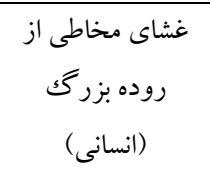 & سويرناتانت & $\begin{array}{c}\text { لاكتوياسيلوس ياراكازئى B } \\
21060\end{array}$ & $\begin{array}{c}\text { Tsilingiri et } \\
\text { al. } \\
(r \cdot \mid r)\end{array}$ \\
\hline (Tr) & اطلاعات كافى وجود & ضد التهابى & 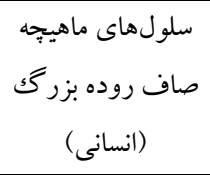 & سويرناتانت & لاكتوياسيلوس رامنسوس & $\begin{array}{c}\text { Cicenia et } \\
\text { al. } \\
(r \cdot 19)\end{array}$ \\
\hline$(F \Delta)$ & اطلاعات كافى وجود & ضد ت سلولى & 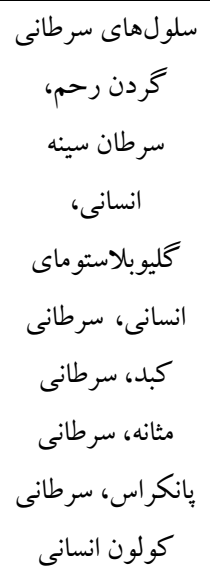 & سلو سيبات داخل & 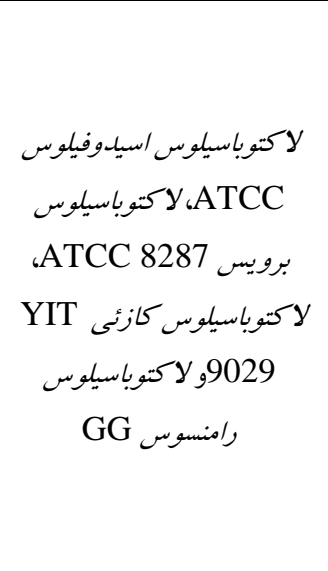 & $\begin{array}{l}\text { Choi et al. } \\
\qquad(r \cdot 4)\end{array}$ \\
\hline
\end{tabular}

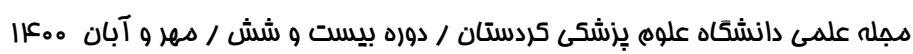




\begin{tabular}{|c|c|c|c|c|c|c|}
\hline (Fq) & اطلاعات كافو وجد & ضد تكثير & سلولهاى سرطان & سوسيانسيون & 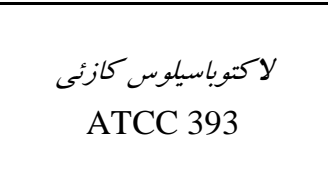 & $\begin{array}{c}\text { Tiptiri- } \\
\text { Kourpeti et } \\
\text { al. } \\
(r \cdot 19)\end{array}$ \\
\hline (FV) & اطلاعات كافى وجود & آنتى اكسيدان & مدل آزمايشكاهى & تر كيبات داخل & 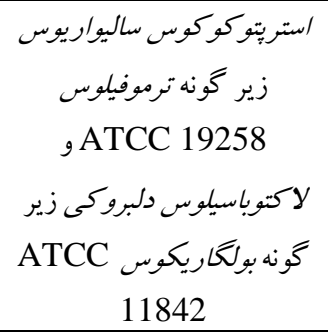 & $\begin{array}{c}\text { Ou et al. } \\
(r+.4)\end{array}$ \\
\hline$(F \wedge)$ & اطلاعات كافى وجود & آنتى اكسيدان & مدل آزمايشگًاهى & سر سيبات داخل & 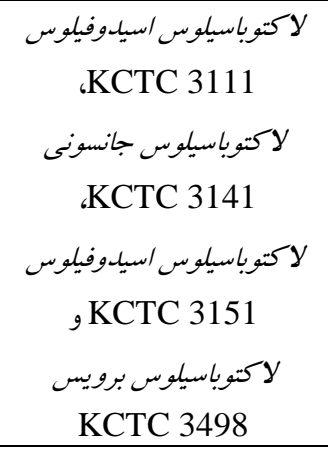 & $\begin{array}{c}\text { Kim et al. } \\
(r . .9)\end{array}$ \\
\hline$(F q)$ & اطلاعات كافى وجود & آنتى اكسيدان & مدل آزمايشكاهى & تركيبات داخل & 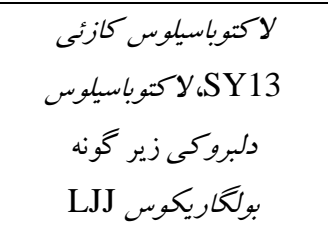 & $\begin{array}{c}\text { Zhang et al. } \\
(r \cdot 11)\end{array}$ \\
\hline$(\Delta \cdot)$ & اطلاعات كافى وجود & آنتى اكسيدان & مدل آزمايشگاهى & تركيبات داخل & 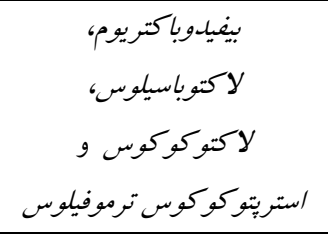 & $\begin{array}{c}\text { Amaretti et } \\
\text { al. } \\
(r \cdot \mid r)\end{array}$ \\
\hline (DI) & اطلاعات كافى & كلسترول سرم & كلس محر ملى موش با & سوسيانسيون & $\begin{array}{l}\text { بيفيدوباكتريوم لانكوم } 1207 \\
\text { SPM } 1207\end{array}$ & $\begin{array}{l}\text { Shin et al. } \\
(r \cdot 1 \cdot)\end{array}$ \\
\hline$(\Delta r)$ & 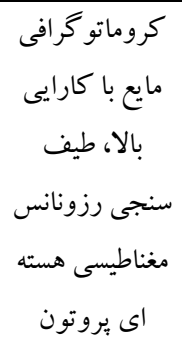 & كاهند خى فشار & صحر مدر موشى مبتلا به & 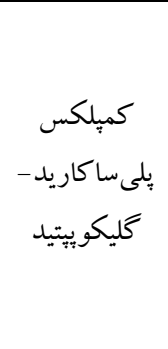 & $\begin{array}{c}\text { YIT لاكتوياسيوس كازئى } 9018 \\
9018\end{array}$ & $\begin{array}{c}\text { Sawada et } \\
\text { al. } \\
(199 .)\end{array}$ \\
\hline$(r q)$ & اطلاعات كافى وجود & ضد جاقى & مدل موش جاق & سلول ليز شده & $\begin{array}{c}\text { لاكتوياسيلوس آميلوروس } \\
\text { CP } 1563\end{array}$ & $\begin{array}{l}\text { Nakamura } \\
\text { et al. } \\
(r \cdot 19)\end{array}$ \\
\hline$(\Delta r)$ & عدم وجود & محافظت كبدى & رده سلولى & سوسيانسيون & $\begin{array}{c}\text { لاكتوياسيلوس فرمنتوم } 110 \\
\text { BGHV } 110\end{array}$ & Dinić et al. \\
\hline
\end{tabular}




\begin{tabular}{|c|c|c|c|c|c|c|}
\hline & اطلاعات كافى & & $\begin{array}{l}\text { سرطانى كبد (انسانى) } \\
\text { (انى }\end{array}$ & ليز شلول & & $(Y \cdot I V)$ \\
\hline$(\Delta F)$ & علدم وجود & محافظت كبدى & موش كشل كاى كبدى داده & تر كيبات داخل & 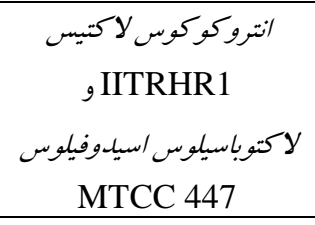 & $\begin{array}{l}\text { Sharma et } \\
\text { al. } \\
(r \cdot 11)\end{array}$ \\
\hline$(\Delta \Delta)$ & اطلاع وجود & ضد ميكروبى & مدل آزمايشگاهى & سويرناتانت & 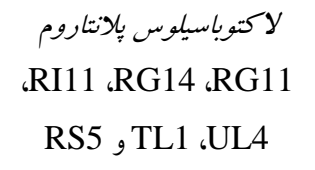 & $\begin{array}{c}\text { Kareem et } \\
\text { al. } \\
(r \cdot \mid \boldsymbol{r})\end{array}$ \\
\hline$(\Delta \varphi)$ & جريف سنجى تكنيك & تعديل سيستم & مونوسيت (انسانى) & لييو تيكوئيك اسيد & ل & $\begin{array}{l}\text { Kim et al. } \\
(r \cdot 11)\end{array}$ \\
\hline$(\Delta \mathrm{V})$ & $\begin{array}{c}\text { ستون } \\
\text { Macro- } \\
\text { prepHigh } \\
\text { Q and } \\
\text { Octyl- } \\
\text { Sepharose } \\
\text { CL-4B }\end{array}$ & تعديل سيستم & $\begin{array}{l}\text { ماكروفازهاى رده } \\
\text { سلولى } \\
\text { RAW264.7 }\end{array}$ & $\begin{array}{l}\text { لييو تيكوئيك اسيد } \\
\text { اسيد }\end{array}$ & 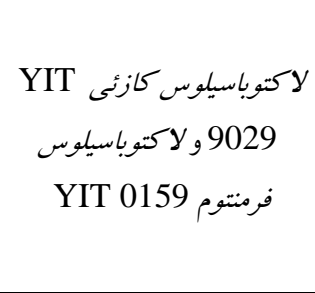 & $\begin{array}{l}\text { Matsuguchi } \\
\text { et al. } \\
(r \ldots r)\end{array}$ \\
\hline$(\Delta \Lambda)$ & اطلاعات كافى وجود & ضعديل سيستم & سلولهاى جنداى & سزاى ديواره & باسيوس كوآكولانس & $\begin{array}{c}\text { Jensen, } \\
\text { Benson, } \\
\text { Carter, and } \\
\text { Endres } \\
(\text { r.l.) }\end{array}$ \\
\hline$(\Delta Q)$ & علدم وجود & ضد القا آيويتى & $\begin{array}{l}\text { رده سلولى } 2 \text { سانى كولون } \\
\text { (Caco-2 } \\
\text { cells) }\end{array}$ & 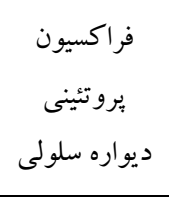 & لاكتوياسيلوس پِراكازئى & $\begin{array}{l}\text { Nozari et al. } \\
(r \cdot 19)\end{array}$ \\
\hline (4.) & اطلاع وجود & 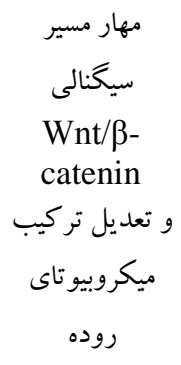 & $\begin{array}{c}\text { رده سلولى } 2 \text { سانى كولون } \\
\text { (Caco-2, } \\
\text { HCT-116 } \\
\text { cells) }\end{array}$ & جربدهاى زوت زتجير & كلستريديوم بوتريكوم & $\begin{array}{c}\text { Chen et al. } \\
(r \cdot r \cdot)\end{array}$ \\
\hline (91) & اطلام وجود & 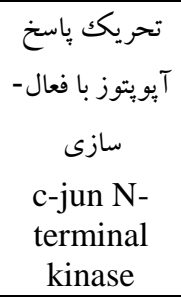 & $\begin{array}{l}\text { رده سلولى } 2 \text { سانى كولون } \\
\text { (SW-620) }\end{array}$ & كويرناتانت & $\begin{array}{c}\text { لاكتوباسيوس كازئى } \\
\text { ATCC334 }\end{array}$ & $\begin{array}{c}\text { Konishi et } \\
\text { al. } \\
(r \cdot 19)\end{array}$ \\
\hline
\end{tabular}

همله علمى دانشكاه علوه بِزشكى كردستان / دوره بيست و شش / همر و آبان م.عاן 
|ع|ا يست بيوتيك ها ...

بافتهاى مختلف در ميزبان دارند و مسى توانـــ جِنـدين ياسـخ زيستى رابه صورت همزمان ايجـاد كنتـد(4, 90). ذكر ايسن نكته نيـز حـائز اهميـت اسـت كـه يسـتبيو تيككهـا نيـز ماننـد تر كيبات برىبيو تيكك، به جـاى افزودن كونـهـهـى جديـد بـهـ ميكروبيو تـاى روده، يروبيوتيـككهــاى موجــود در دســاه كوارش هر فرد را توسعه مسىدهنـد(19, 99). ايسن امـر بيـانكر ضـرورت بررسـى ايمنسى، بهينــهــازى روشهـاى مختلـف استخراج و شناسايى تركيب شيميايى يستبيوتيكها و بررسى نقش فيزيولوزيكى آنها در سيستمهاى بيولوزيكى مىباشد كه موجسب تسهيل در بـه كـار گيرى تر كيـات بسـتبيو تيكك در فرمولاسـيونهــاى دارويـى يـا غـذايى مسى شـود (شـكل r).
به طور كلهى بِــتبيوتيـك هـا بـا توجـه بـه سـاختار شـيميايى مشخص، داشتن نمايه ايمن، ماند كارى طولانى و اين كه حاوى مولكول هاى مختلف سـيخنالينگك هسـتند، داراى فعاليـتهـاى

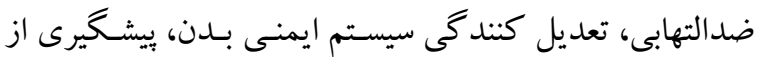
جاقى، تعديل كنندگى فشارخون، كاهنـدگى كلسـترول سـرم، متوقف ساختن تكثيـر سـلولى و آنتى اكسـيدانى بـوده و نقـش اساسى و بالينى بروبيو تيككهـا را ايفـا مسى كنتـد و همبجنـين در طيف وسيعى از محصولات غـذايى مـورد اسـتفاده قـرار مـى كيرند( (q). علاوه بر اين، تحقيقات انجام شـده(ب) نشـان داد كه يسـتبيو تيككهـا توانـايـهـاى جـذب، متابوليسـم، توزيـع مناسب و همجينين ظرفيت بالايى براى سيخنالينگك با اندام ها و

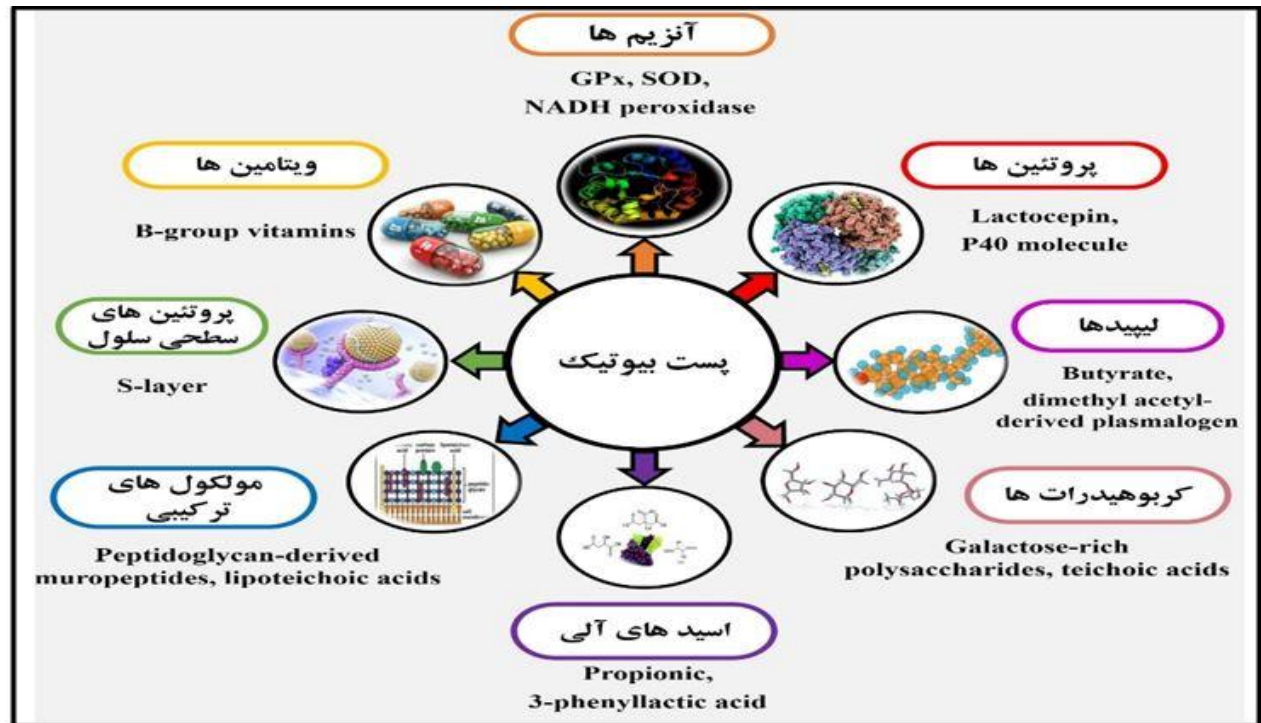

شكل ז. انواع يستبيوتيككها همرا با اثرات سودمندى براى ميزبان.

برخى از بروبيو تيككها مى توانند واكنش التهابى موضعى شـبيه واكنش ناشى از حضور كونههاى سالمونلا ايجاد كنند. عـلاوه بر اين، مشاهداتى مرتبط با مصرف بـاكترىهـاى بروبيوتيك زنده (ايجاد نفخ، تغيير مكان به خارج از محسيط روده، حضور باكترى در خون و انتقال احتمالى زن مقاومست آنتى بيـو تيكى) كزارش شده است و در مـواردى اخـتلالات عمـده (سـركوب
ايمنى بستبيو تيكك ها: شواهد حاكى از آن است كه يستبيو تيككها مىتواند اثرات سلامتى بخش يروبيو تيككها را داشته باشند، البته اين در حسالى است كه مصرف مواد غذايى حاوى بروبيوتيـك زنـده ممكـن است هميشه بى ضرر نباشد. در سـال r| ب در يـك آزمـايش در مدل برون جانـدارى (Fx vivo) (FF) مشـاهده كردنـد كـه 
ريز مغذىها (Micronutrients) بود. ديخر كار آزمايىهـاى امباسي

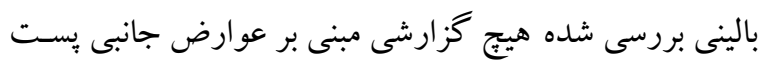

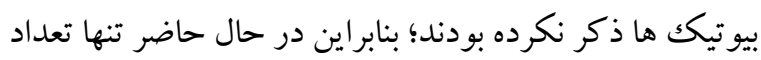

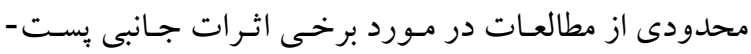

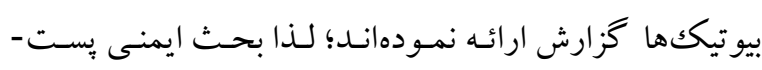

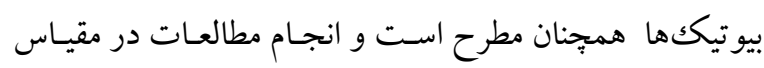

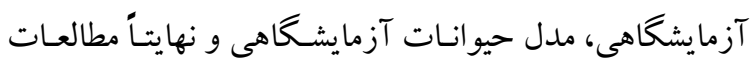

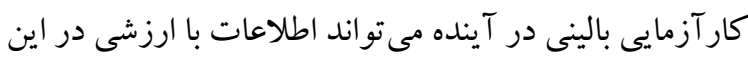

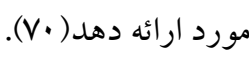
روش هاى شناسايى، جداسازى و توليد بِت بسيو تيككها

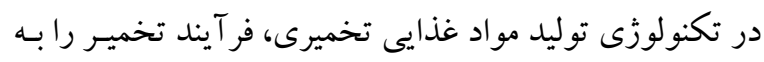

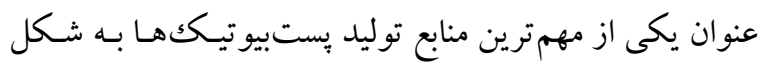

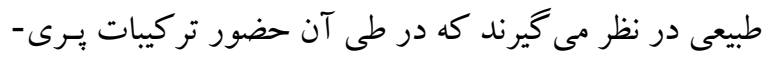

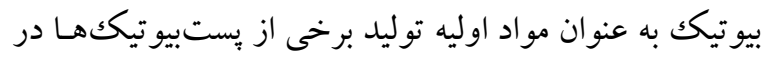

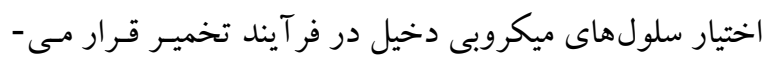

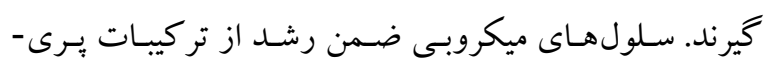

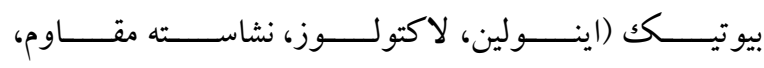

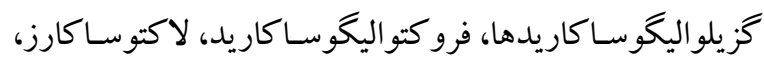

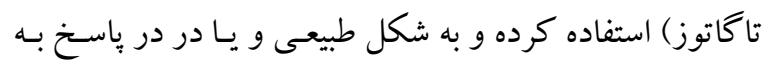

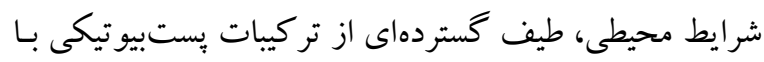
خواص مختلف زيستى (ضد ميكروبى، آنتى اكسيدانى، ضـد

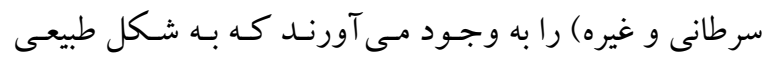

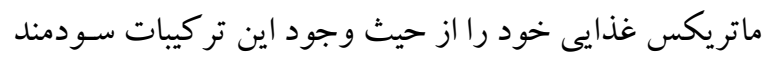
غنى سازى مى كنند (VI). علاوه بـر روش طبيعى توليـد يســ-

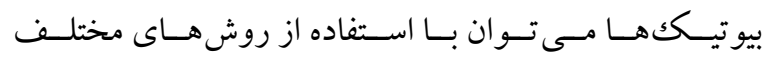

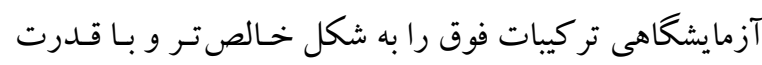

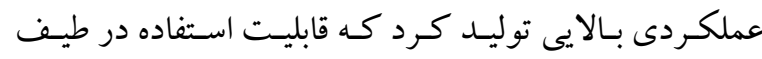

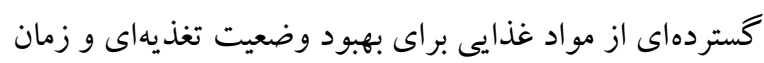

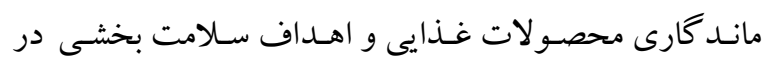

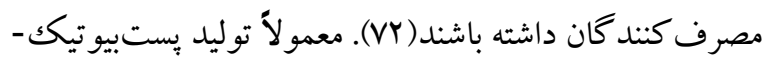
ها شامل تكنيككهاى تخريب سلولى ماند تيمارهاى حرارتى و
سيستم ايمنى بدن، نوزادان نارس) و اختلالات جزئى (اختلال

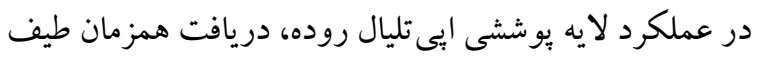

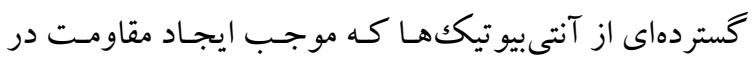

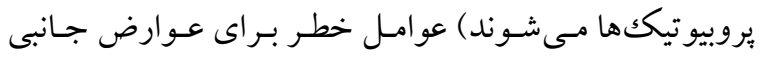

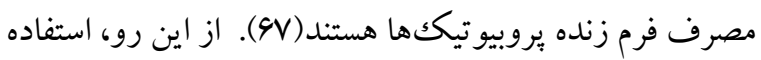

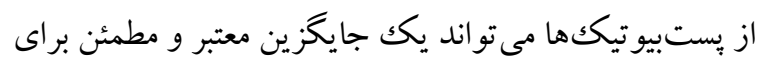

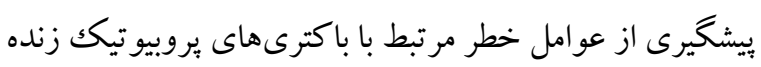

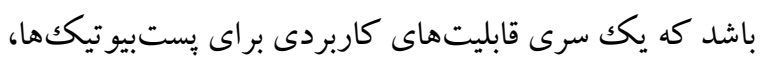

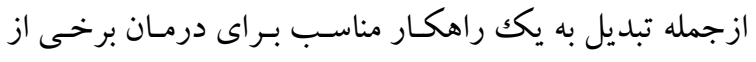
بيمارىها را در بيى دارد(91). با توجه به بحث ايمنى پِّتبيو تيككها، نتايج به دست آمـده از

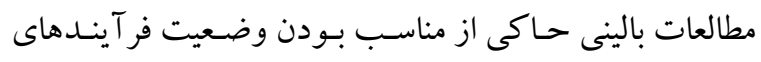

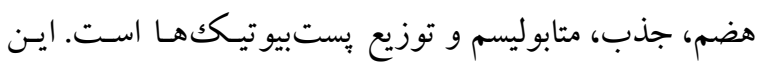

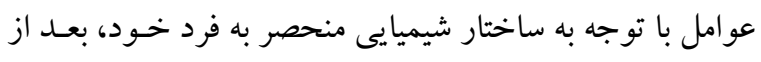

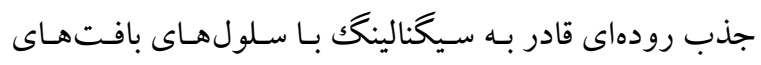

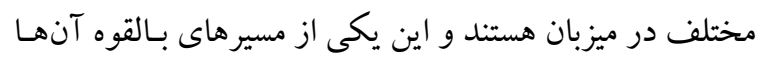

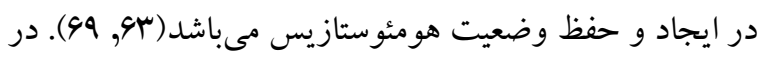

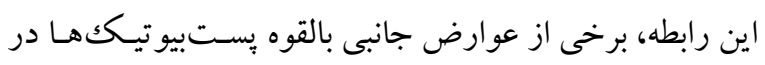

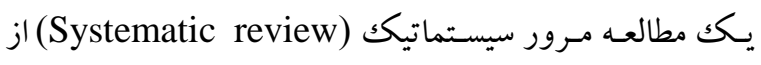

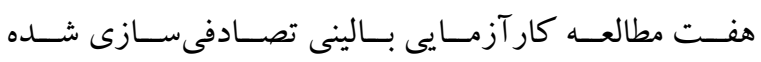
(Randomized controlled clinical trials) TIVF. كود كو مورد بررسى قرار گرفت. در اين مطالعه

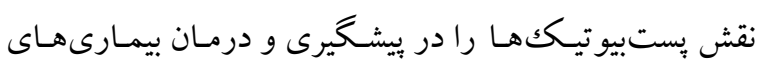

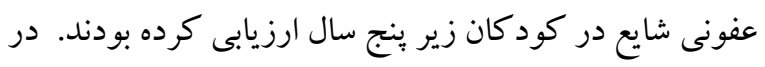

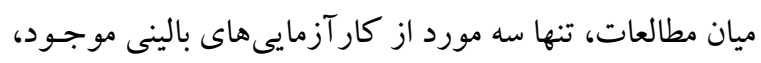
اثرات جانبى بست بيو تيكها را به طور مشخص ارزيابى كرده

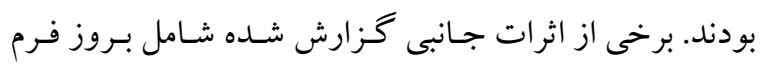

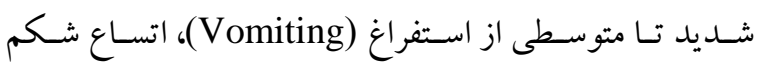
و همجنــين بــروز كـمـ آبسى (Abdominal distension)

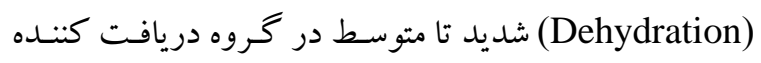
فرم غيرفعال شده لاكتوياسـيلوس /سـيلوفيلوس LB بــ همـر اه 
يروبيو تيـك هــا را از خـود نشـان مسى دهنـــ. بـه عنـوان مثـال، مكانيسـمهـاى كاهنــده كلسـترول سـرم توسـط بـاكترىهـاى يروبيوتيك شامل مهار جذب كلسترول در روده و يا مهـار بـاز جذب اسيدهاى صفراوى است. از سوى ديكر بستبيو تيك ها، كيرنده فعال كننده تكثير براكسىزومها را فعال كرده و موجب بتا اكسيداسيون اسيدهاى جرب و كاهش ترى كليسيريدها مى -

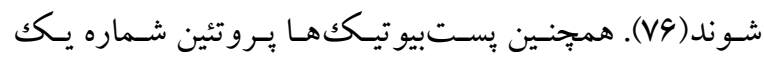
اليكومريزاسيون حاوى دومين متصـل شـونده بـه نو كلئوتيـد را فعال مى كنند كه باعث ايجاد ليِيوليز مستقل سـلولى در سـلولهاى جربى مى شود تا فعاليت آنزيمى ب-هيدرو كسى -ب- متيـل

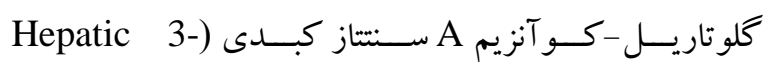
و و rhydroxy-3-methylglutaryl-CoA synthase 3يدرو كسى -ب-متيـل كلوتاريسل ردو كتـاز (-hydroxy-3 (methylglutaryl-CoA reductase AMP-activated ) AMP يسروتئن كينـاز فعـال شــده بـا (protein kinase

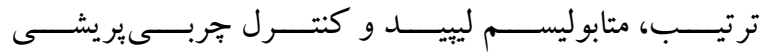

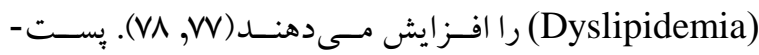
بيوتيككهايـى از جنس موراميـل دى ييتيـد، مـىتوانتـد التهاب سلولهاى جربى و عدم تحمل كلو كز را از طريق فعـالسـازى يروتئين شماره دو اليخومريزاسيون حاوى دومين متصل شـونده به نو كلئو تيد و همجينين با فعالسازى عامل رونويسى IRF4 در

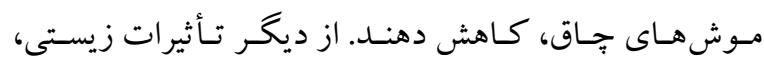
مى توان به كاهش مقاومت به انسولين اشاره كـرد(V9). يُّـبيو تيـك هـا همجنـين داراى فعاليـت ضـدسـرطانى هسـتند كـه مربوط به فعـال شـدن مسـيرهاى آيويتـوزى (Apoptosis) از طريق تنظيم ياسخهاى سيستم ايمنى مىباشد(F4). طبـق يافتـه هاى مطالعات بيشين، يستبيو تيككهـاى حاصـل از سـويههـاى لاكتوباسيلوس باعث كاهش فعاليـت متالويرو تئينـاز -9 و مهـار سرطان كولون مسىشـوند (•). فعاليـت ضـدميكروبسى يسـت بيوتيككها نيز ناشى از حضور جِندين تر كيبات شـناخته شـده و
آنزيمسى، اسـتخراج توسط حسلال و همجنـين توسط دســاه سونيكاتور مىباشد كه به دنبال آن مراحلى از جمله استخراج، سانتريفيوز، دياليز، خشـك كـردنانجمـادى نيـز بـراى افزايش بازده توليد و نكهدارى از اين تركيبات مورد استفاده قرار مى -

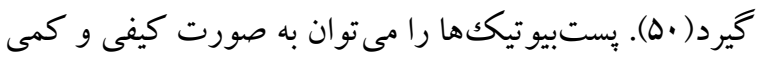
شناسايى كرد. مىتوان از طيف سـنجى رزونـانس مغناطيسى هستهاى يروتون ( Proton nuclear magnetic resonance (spectroscopy

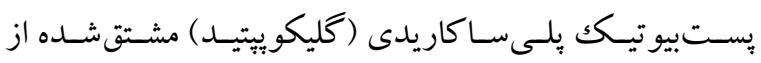
لاكتوباسـيلوس كـازئى استفاده كـرد. همجنسين در مطالعـات

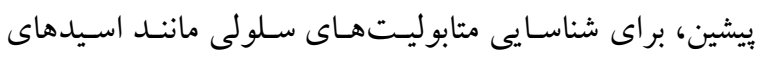
جربزنجيرهاى، كليسـروليييدها، يـورينهـا، اسـنـخوليييدها و

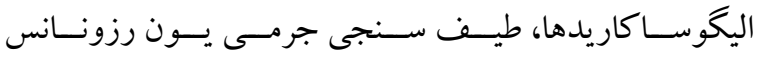

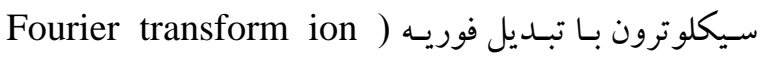
(cyclotron resonance mass spectrometry استفاده قرار كرفته است(سY, VF). علىرغم وجـود روش هـاى بحث شده، امروزه جالشهاى زيادى در مورد تر كيبات يستبيوتيـك وجـود دارد و فرصـت زيـادى را بـراى يثزوهشـخران جهت انجام مطالعات بيشتر براى بررسى دقيقتر ماهيت يسـت بيو تيككها، بهترين روش هاى شناسايى، اسـتخر اجى و خـالصسازى براى هريكك از اجزاى عملكردى بِت بيو تيككها فراهم مى كند كه به نوبه خود موجب شـناخت بيشـتر ايسن تركيبـات، تاثير ات سلامت بخش آن، امكان به كار گيرى گسـتردهتر در حوزه يزشكى، داروسازى و غذايى و در نهايت منجر بـه ارتقـا وضعيت سلامتى ميزبان (انسان يا حيوانات) خو اهد شد(VD).

مكانيسمهاى بالقوه مؤثر در زيست فعالى يستبيوتيككها: عليرغم اثرات مفيد پِت بيو تيك ها، مكانيسم عمل آنها هنوز به طور كامل شناسايى نشده است. يستبيو تيككهـا معمـولاً بـا مكانيسـمهــاى عمـل متفــاوتى، اثــرات مفيـــ و درمـانى مشــابه 


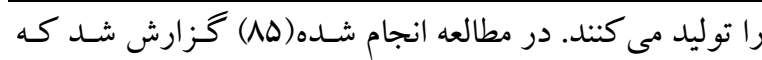

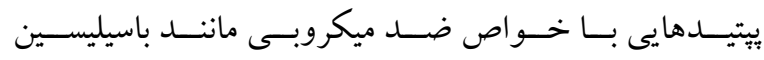
و كلروتتائين (Bacilysin)

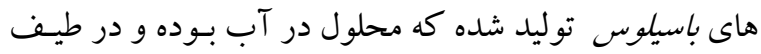

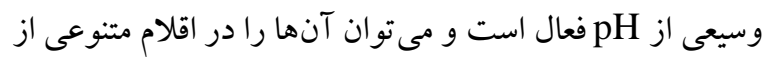

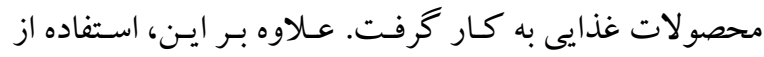

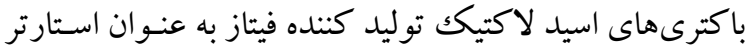

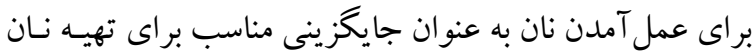

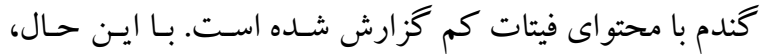

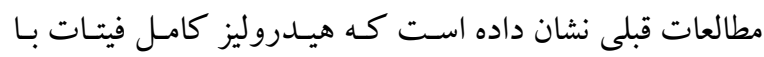
افزايش زمـان تخمير و يـا كـاهش pH در طلى تخمير كامـل

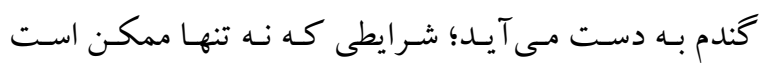

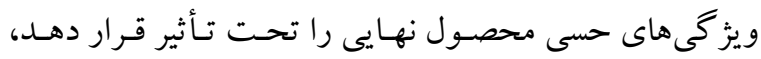
بلكه مى توانند بر سنتز آنزيمهاى تخريب كننده فيتـات توسط

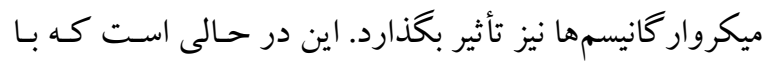

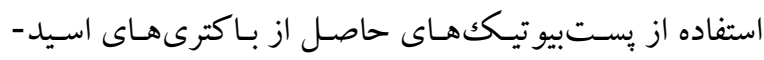
لاكتيك مى توان ميزان فيتات در محصول نهايى را بـا كمترين تغيير در ويز گىهاى حسى محصسول كاهش داد (19). اخرجـهـ يستبيو تيككها در جندين ماده غذايى به طـور طبيعى حضور

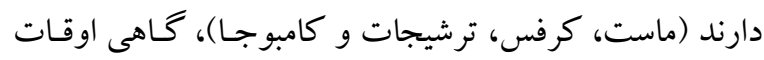

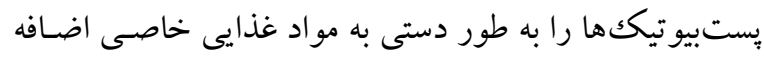
مى كنند، بدون اينكه سويههاى باكتريـيى موجـود در آن غـذا بـا در توليد آنها نقش داشته باشند. به عنسوان مثـال، سـويرناتانت

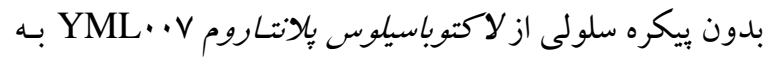

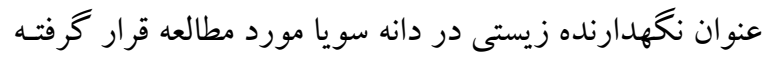
و به اين نتيجه رسيدهاند كـه ايـن تركيـب موجـب بهبـود عمـر

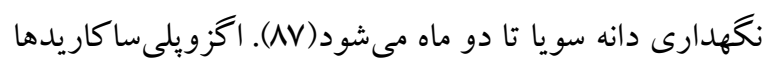

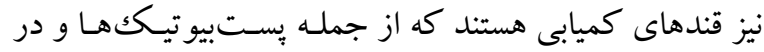

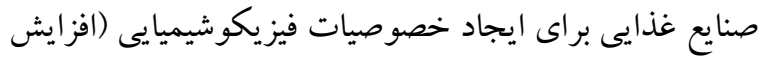

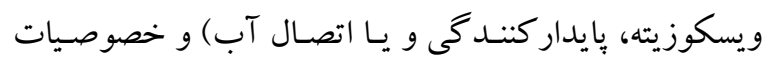
حسى (خـوش طعـم بـودن (Palatability)) در محصـولات
ناشناخته ضدميكروبى مىباشد كه معمولاً شامل باكتريوسينها،

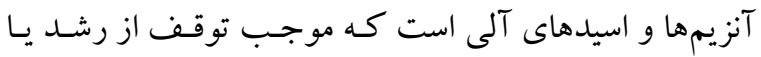
نابودى باكترىهاى كرم منفى و مثبت مىشوند (1)). همه ايـن

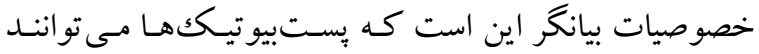

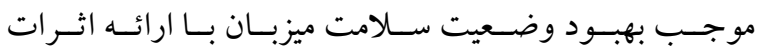
فيز يولوزيكى خاصى گردند هر جند كه مكانيسـم دقيـق آنهـا هنوز شناخته نشده است. كاربرد بالقوه بِت هييو تيككها درصنايع غذايى:

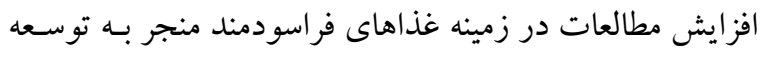
نسل جديدى از اين محصولات، از جمله غذاهاى يروبيوتيكك

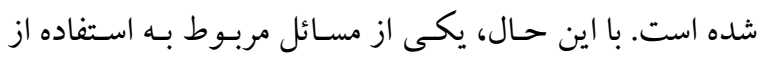

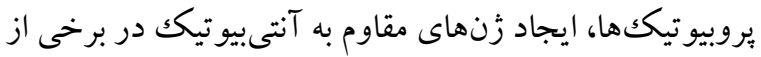

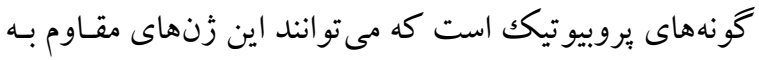

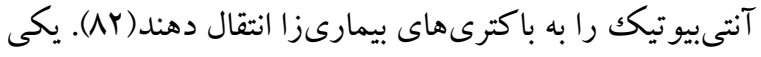

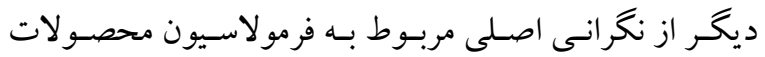

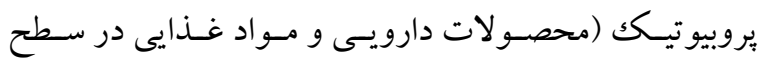
تجارى) حفظ حيات بـاكترى در حين توليـد و ذخيرهسـازى

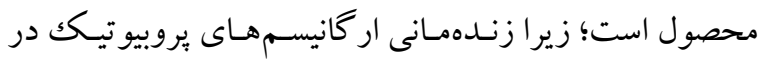
يـك سيسـتم تحويـل (فرمولاسـيون دارويسى و محصـولات غذايى) مى تواند تحت تاثير متغيرهاى مختلف، از جمله تعامـل

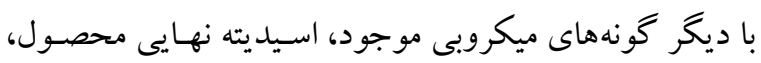

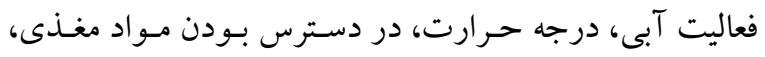
مهار كنندههاى رشد، دوز تلقيح باكترى، زمان تخمير، اكسيرن

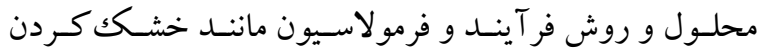
انجمـادى، خشـك كـردن افشـانى يـا تغلـيظ انجمـادى قـرار بحيرند(r). علاوه بر اين، در مواردى تفاوتهايى بين شـمار

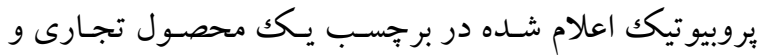
شمار واقعى آن وجـود دارد؛ از ايـن رو ايـن عـدم بايــارى و

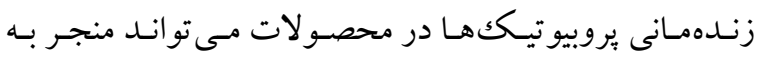
كاهش اثرات سلامتى بخش مورد انتظار گرددد(AF). در مقابل،

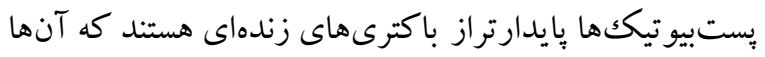




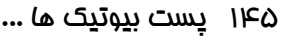

محصــولات شـيلاتى مانـــد مــاهى و نـــرمتـــان صــدفدار، محصولات لبنـى مانـــ شـير، كنـدم، سـويا، تخـممـرغ، انـواع آ جيل ها و دانهها اشاره كرد(سه). يثزوهش هايى كه با محوريت بررسـى نقـش ميكروبيو تـاى روده در ارتقـاء سـلامت ميزبـان طراحى شده بودند، بيانكر وجود يكك ارتباط مستقيم و بيتيجيده بين تر كيب ميكروبيوتاى روده با عملكرد سيستم ايمنى بودنـد.

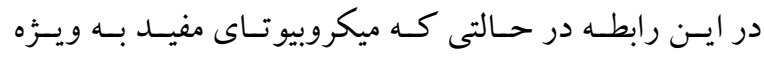
يروبيو تيككها در محيط روده غالب مسىشـوند از طريست ايجـاد ارتباط با سلولهاى ايسى تليـال و سيستم ايمنسى علائسم آلرزى غذايى در افراد مبـتلا را تعـديل ميكنتـد(qf). طبـق شـواهد بـهـ دست آمده از مطالعات بالينى، يست بيو تيكك ها بـه ويـزه اسـيدهاى جرب كوتاه زنجير از جمله بوتيرات نقش جشـمَيرى در كاهش علائم آلرزى غذايى در ميزبان دارند. يُستبيوتيك هـاى مذكور با سلول هـاى سيستم ايمنسى ميزبـان وارد واكـنش هـاى القائى شده و موجب كاهش حساسيت ميزبان در مقابل آنتى -

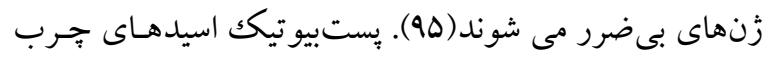

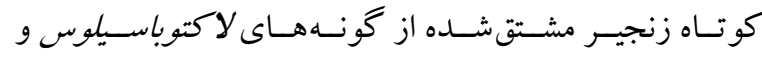
بيفيلوباكتريوم ضمن اينكه منبع انرزى مهمى براى سـلولهـاى

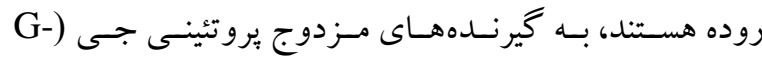
protein-coupled receptors سلولهاى كولونوسـيت، انتروسـيت و سيستم ايمنسى)، متصل شده و سلولهاى دنـدر تيكك ايسى تليـال و ماكروفازهـا را بـراى توليد اينترلو كين · ا (Interleucin-10) تحريك مى كننـد، از سوى ديخر نيز موجب توسعه لنفوسيتهاى تى تنظيم كنتـده در كرههاى لنفاوى مزانتريك مى شوند كه در نهايت (Tregs) منجر به مهار بِاسخ هاى التهابى و آلكرزى ناشـى از غـذا مسى -

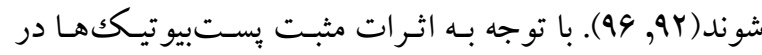
ايجاد ارتبـاط منسجمم بـا سيستم ايمنسى و برقـرارى ياسـخهاى ايمنى مناسب در جهـت كـاهش حساسـيت ميزبـان بـه حضـور

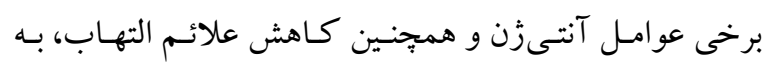

غذايى مورد استفاده قرار كرفتهاند. با ايسن وجـود، بـه اسـتثناى دكستران، توليد و كاربرد اگزويلىساكاريد باكترىهاى اسيدلا كتيكك به به عنوان مكمل هاى غذايى نياز به تحقيقـات بيشـتر

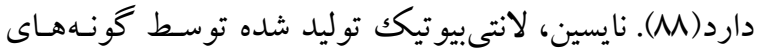
خـاص لاكتوباســيلوس لاكتـيس زيسر كونـه لاكتـيس، تنهـا باكتريوسينى است كه براى استفاده به عنـوان نخههدارنـده مـو اد غذايى تاييده سازمان غذا و دارو آمريكا ( Food and Drug (Administration غذايى حاوى نايسين مىتوان به سوبِهـاى كنسـرو شـده، يـخ براى ذخيره ماهى تـازه، غـذاهاى كـودك، محصـولات بختـه شـده، سـس مـايونز و محصـولات لبنسى بـه ويـزّه ينيـر اشـاره كرد(19). باكترىهاى اسيد لاكتيكك مـورد اسـتفاده بـه عنـوان استارتر در محصولات لبنى تخميـرى مختلـف توسـط سـازمان

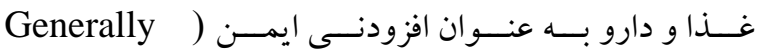
(recognized as safe محصولات لبنى تخميرى، باكترىهاى بيروبيوتيـك بـه محسيط روده رسيده و مى توانند متابوليتهـايى مانــد يِّيـدو گليكان و باكتريوسين را توليدكنند. ديخر محصولات طبيعى تخمير شده مانند ترشى، كيمجى (kimchi)، كلـم نيـز بـه عنـوان يكى از منابع بستبيو تيككهـا جهـت ايجـاد اثر ات سـلامتى بخشش بـــ

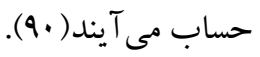
از كاربردهاى بالينى بِّتبيوتيـكهـا در بحـث غـذا و تغذيسه، مى توان به نقـش مثــت آنهـا در آلرزى غـذايى اشـاره كرد. آلرزى غذايى نوعى اختلال سيستم ايمنسى محسـوب مسىشـود كه تأثير زيادى بـر كيفيـت زنـدكى مبتلايـان دارد( (9). در دو دهه بيش شيوع علائم بالينى مرتبط با آلرزى غذايى به ويزه در

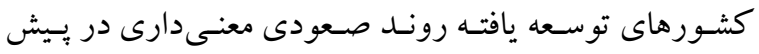
كرفته كه از لحاظ اقتصادى نيز حائز اهميـت اسـت (9Y). طبـق نتايج مطالعات صورت گرفته بـر روى طيسف وسـيعى از مـو اد غذايى، بيش از صــ و هفتـاد نسوع مـاده غـذايى در ارتبـاط بـا

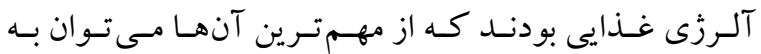


راهبرد زيستى ميكروبـى بـه عنـوان درمـان مكمـل بسـيارى از

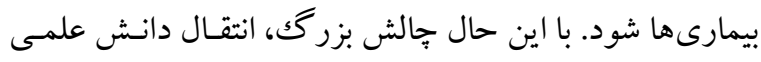
به برنامههاى كاربردى تجارى است كه به منزله ايجاد يـل بـين

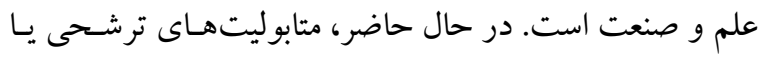

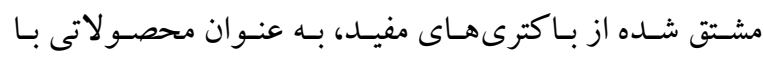

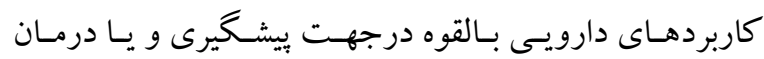
Colibiogen بيمارىها معرفى مىشوند (99). به عنوان مثـال، يكك محصول مشتق شده از كشت/شريشياكلى است كه حاوى

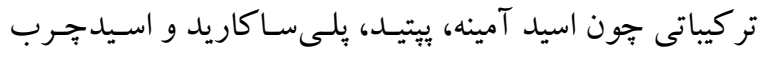

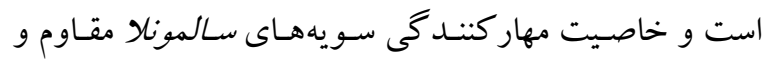
حساس به آنتى بيوتيكك در مدل آزمايشگاهى را دارد؛ همجنين در بهبود كوليت رودهاى و بـه طور قابـل توجههى در كـاهش ضايعات يوستى در بيماران مبتلا به “ polymorphous light

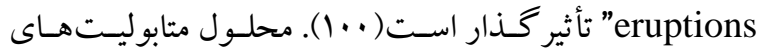
بدون يِيكره باكترى (اسيد جرب كوتاه زنجير، اسيدلاكتيكك و

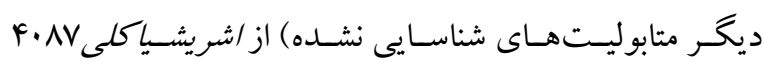

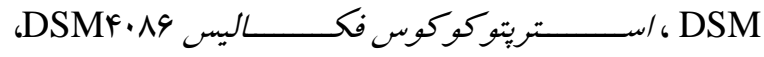
لاكتوباسـيلوس /سـيدوفيلوس DSM F FIF و لاكتوياسـيلوس هلويتيكوس سNAFIN در درمان سالمونلوزيس در نسوزادان و همجينين در درمان ديسباكتريوزيس (عدم تعـادل باكتريـيى)

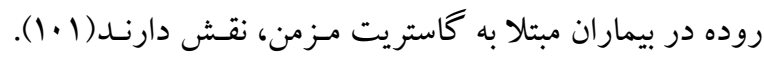
CytoFlora

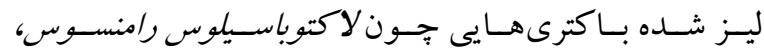

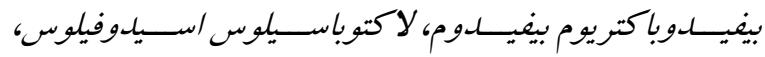

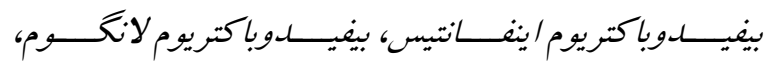

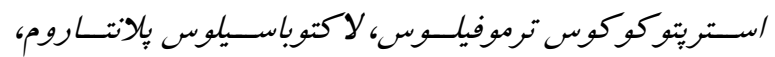

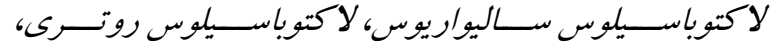

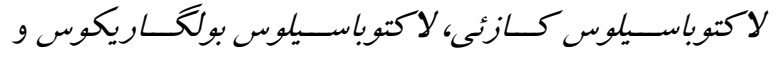
لاكتوباسيلوس /سيروثنز است كه براى اصلاح ديسبيسوزيس بيس لوسيس (عدم تعادل باكتريـيى) روده اي و بهبـود پياسـخ ايمنسى مـورد

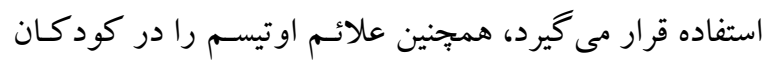

عنوان راهبردى نوين در بهبـود آلرزى هـاى غـذايى محسـوب

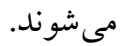
طبق شواهد موجود، بِتبيوتيككها مى توانند نقش مؤثرى در كاهش علائم بيمارى عدم تحمـل لاكتـوز داشـته باشـند. عـدم تحمل لاكتوز نوعى اختلال دستخاه گَوارشى شـايع در گستره

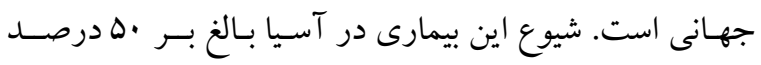
تخمين زده شده است و در بعضى كشورهاى آسـيايى بـه ... درصد نيز مسىرسـ(QV). ايـن بيمـارى را مى تو ان بـا وجـود

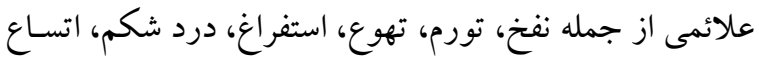

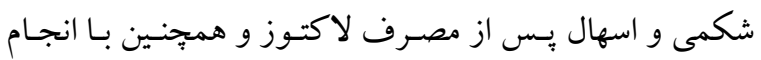
آزمايش Hydrogen Breath Test)HBT) تشخيص داد. مطالعهاى كـه توسط رامِنخـان و همكـاران انجـام شـد، تـأثير تجويز ساشههاى حاوى تركيبات بِـتبيو تيكك (Dialac) را در كود كان مبتلا به عدم تحمل لاكتوز بررسى كردند. در ايـن

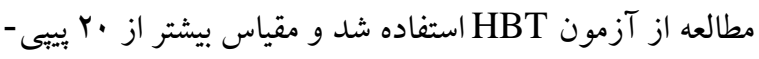

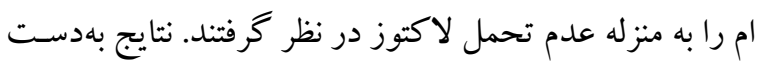
آمده حاكى از كاهش معنى دارى در مقيـاس HBT مبتلايـان

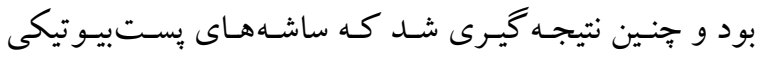
پيانسيل قابل قبولى در كاهش علائم بيمـارى و بهبـود وضسعيت كود كان مبتلا به عدم تحمل لاكتوز داشته و مى تو انند براى اين منظسور وارد عرصسه توليسـ صـنعتى شــده و در جهـت ارتقــاء وضعيت سلامت افراد به كار گرفته شوند(ه1). كاربرد بالقوه يستبيو تيككها در صنايع دارويى:

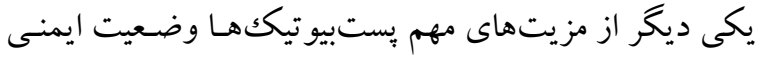

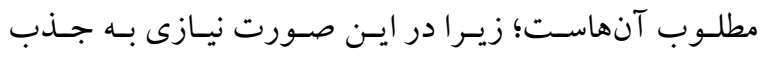

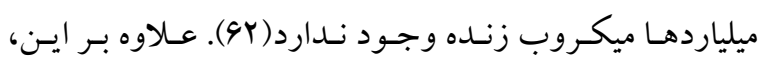

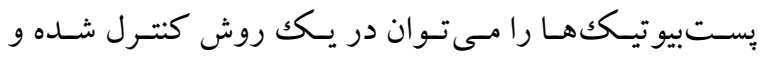
اسـتاندارد اسـتفاده كــــ؛ در حسالى كـه در مـورد اسـتفاده از باكترىهاى زنده، عملكرد باكترى در روده بستگى به تعـداد و فعاليت متابو ليكى سويه مربوطه دارد؛ بنابراين، تركيبات محلول

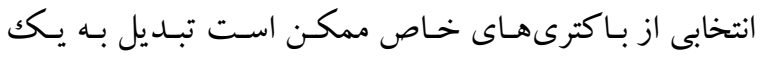


ييشخيرى از تهاجم به سـاير بافـتهـا، مهار تشـكيل بيـوفيلم و

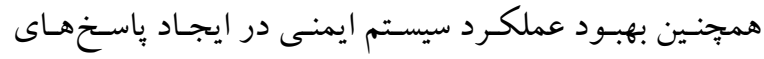

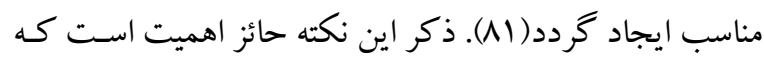
علاوه بر باكترىهاى اسيد لاكتيك، بست بيو تيككهـاى مشتق

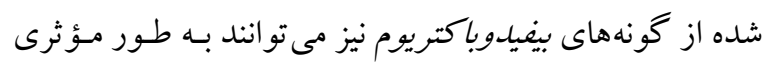

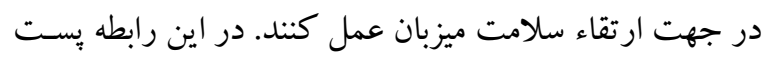

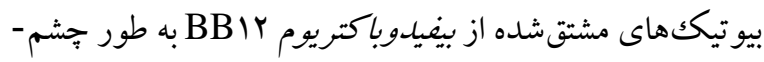
كيرى از تشكيل و توسعه بيوفيلمهاى /ستريتوكوكوس موتانس در حفره دهانى بيشخيرى كردند(1+1). از سوى ديخر، نتايج

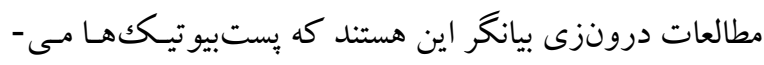

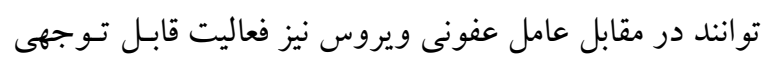

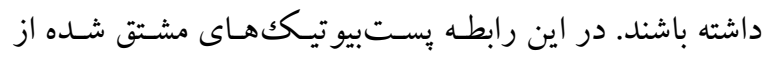

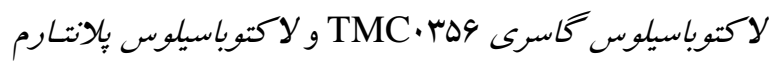
L- IrV

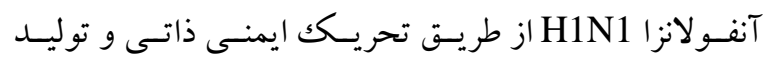

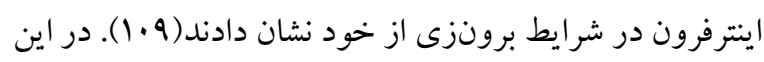

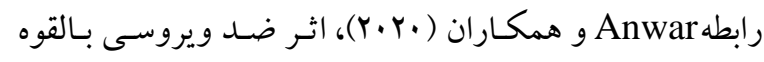

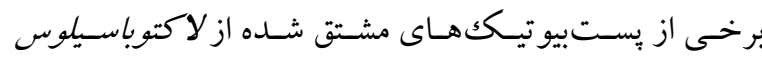

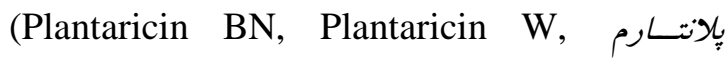
Plantaricin D, Plantaricin JLA-9) با هدف بلو كه كردنمesidual binding protein بـر روى

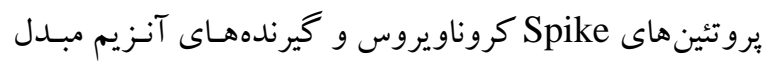

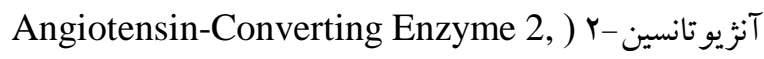

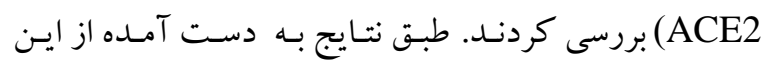

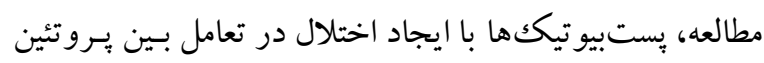

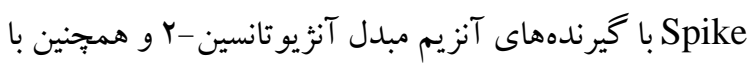
بلو كه كردن Residual binding protein بر روى بروتئين هاى Spike كروناويروس، مى تواند به عنوان ززينهاى ايمن و اميدوار كنــده در طراحى واكسن و كـاهش حسدت بيمـارى

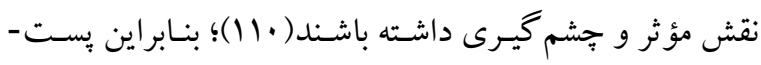

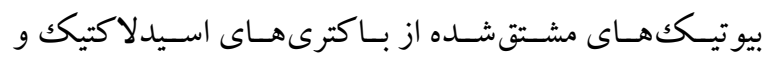

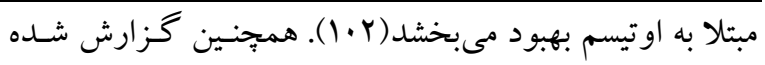

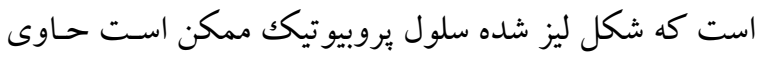

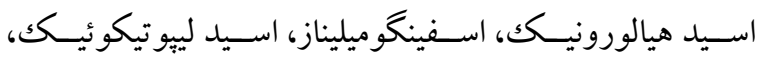

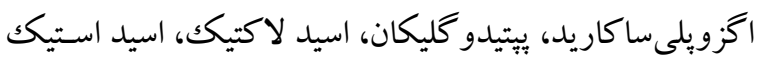

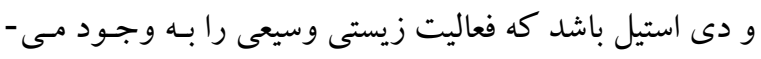

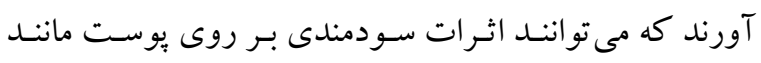

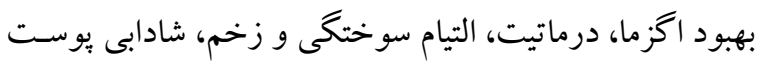

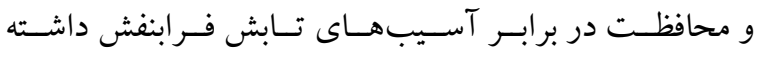

باشند(r +1). طبق شواهد موجود از مطالعـات بـالينى، همـواره يـك ارتبـاط مستقيم و منسجم بين ميكروبيوتاى مفيد روده (بروبيوتيككها)،

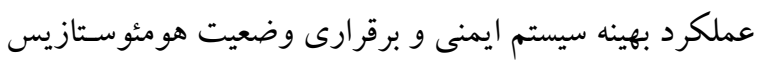

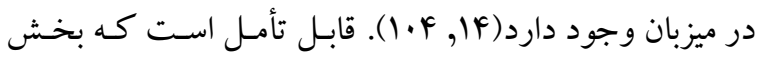

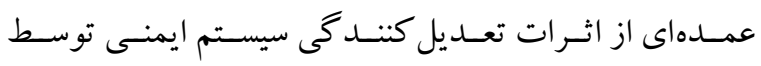

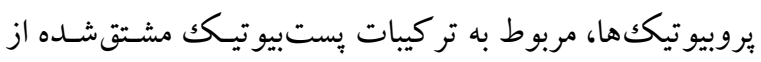

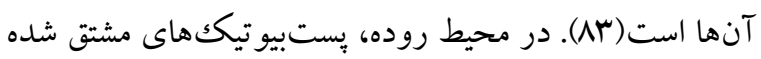

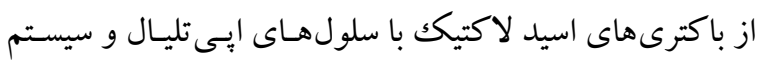

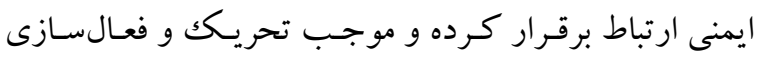
ايمنى ذاتى و متعاقباً راهانـدازى ياسـخ دفـاعى آنـى در ميزبـان

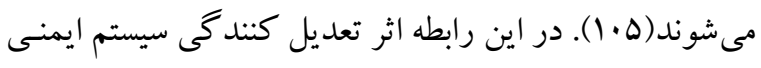

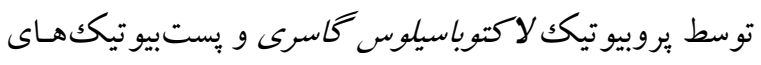

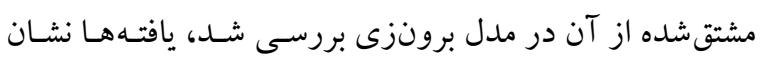

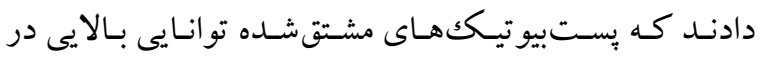
Interleucin-) I تحريك سيستم ايمنى و توليد اينترلـوكين

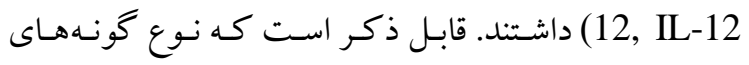
ميكروبى، انواع روش هـاى غيرفعالسـازى و حفـظ دوز مـؤثر

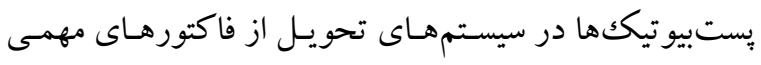

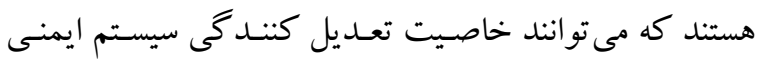

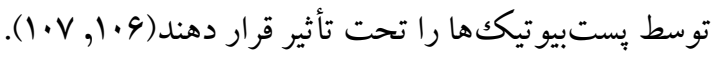
توانايى بست بيو تيككها در حفظ سلامتى ميزبان در برابر عو امل

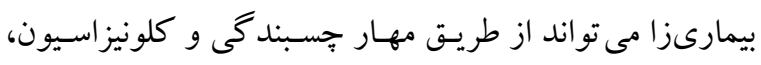


رابطه در يكك مطالعه كار آزمايى بـالينى تصـادفى، مبتلايـان در

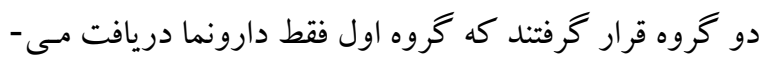

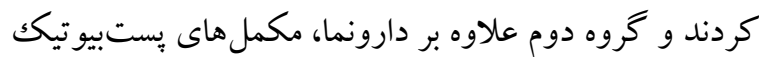

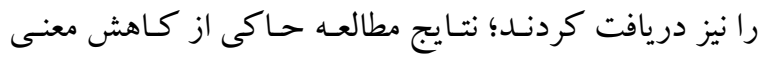

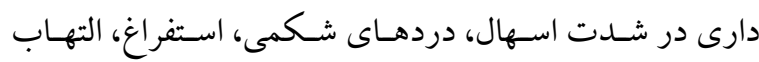
مخاط حفره دهانى، آتروفى، آسيبـهـاى بوستى، اخستلالات

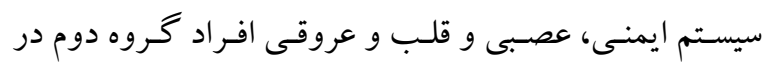

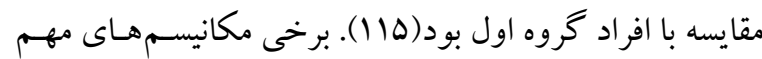

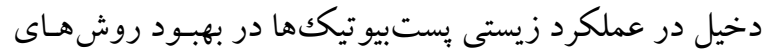

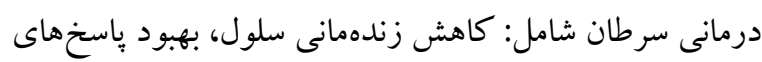

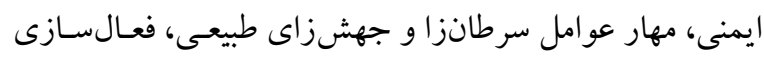

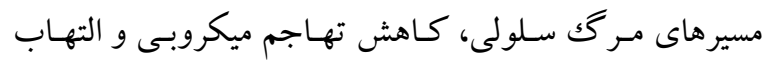

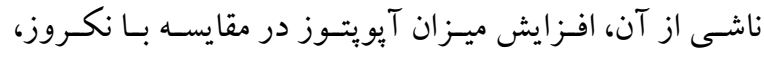

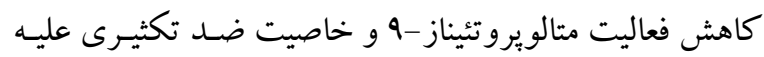

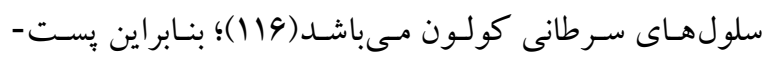
بيو تيككها با بهبود روشهاى درمانى و كاهش اثرات نامطلوب آنها مى توانند در قالب سيستمهاى تحويل دارويى يـا غـذايى ليى در كنار ديخر روش هاى درمانى به كار گرفته شوند.

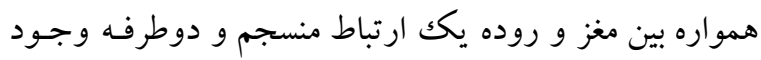

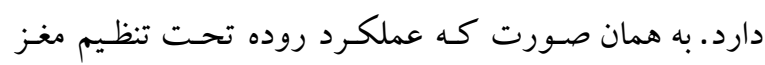

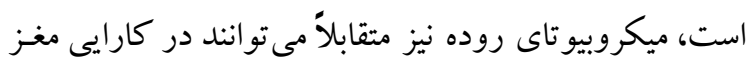

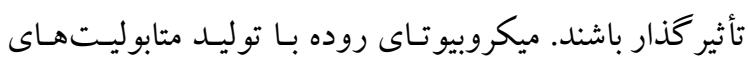
مختلف (يست بيوتيككهـا) و تحريكك توليـد هورمسونهـاى

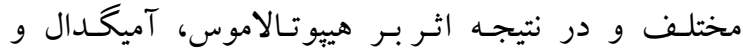
هييو كامب، بسيارى از رفتار و اعمال انسان را تنظيم مى كنتـد.

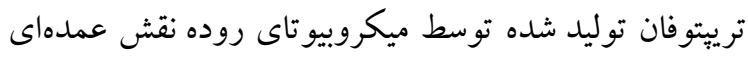

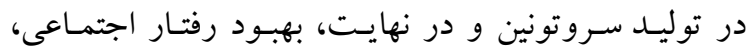

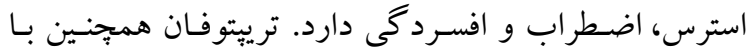
تنظيم احساس سـيرى، نقـش بـهسـزيى در جـاقى دارد. بـروز وضعيت ديسبيوزيس در ميكروبيو تاى روده (ناشى از استفاده

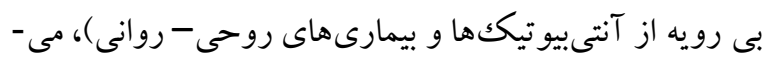

بيغيدوباكتريوم را مى توان به عنوان عامل ضدميكروبى ايمن در طيف وسيعى از محصولات دارويى جهت اهداف بيشخيرى يا بهبـود روش هـاى درمـانى و همجنـين در محصـولات غـذايى جهت به تـأخير انـداختن فسـاد و افز ايش مانـد كارى بـه كـار كرفت. علاوه بر موارد ذكر شده، مسى تـوان بـه نقـش منحصـر بـه فرد بست بيو تيككها در بهبود روش هاى درمـانى سـرطان بـه عنـوان رويكــدى جديـــ در كنـار روشهـاى معمـول درمـان اشـاره

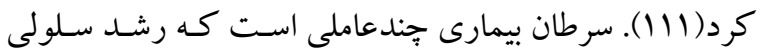
نامنظم و غيرقابل كنترل از بارزترين ويزگ كى هـاى آن محسوبـ مىشود(1/Y). از جمله روش هاى درمانى معمول سرطان مسى توان به راديو درمانى، ايمنىدرمانى، شيمىدرمانى و يا جراحى

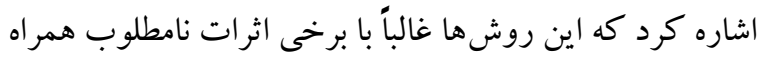

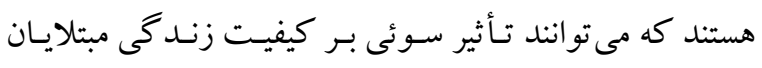
داشته باشند(س||(1). در ايـن رابطه از برخسى مهـمترين اثـرات

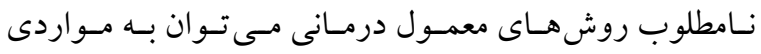

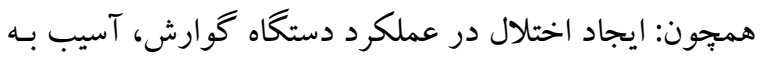
سيستم عصبى محيطى، تغييـر عملكرد غـدد درونريـز، ايجـاد اخستلال در عملكـرد سيستم ايمنسى، تنفسى، قلـب و عروقىى، آنمى، درد و ضعف عضلانى، خستكى، اسـهال و آسـيبهـاى

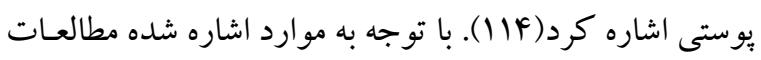
اخير سعى در به كارگيرى روشهاى درمانى با كمترين اثرات

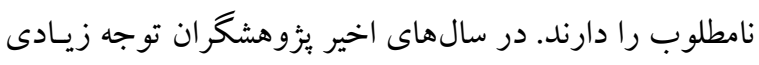

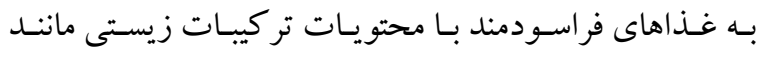

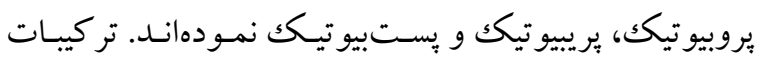

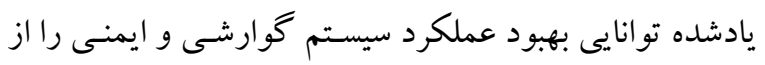

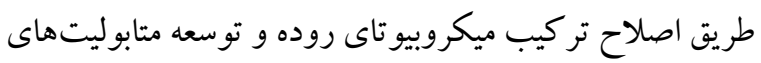

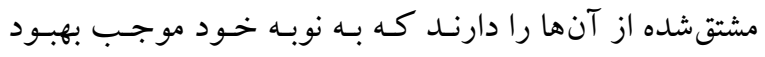
روش هاى درمانى معمول و كاهش اثرات نـامطلوب آنهـا در

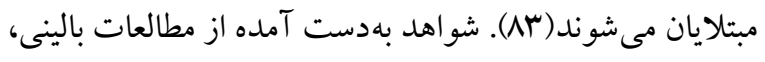

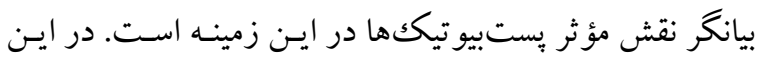


وعا يست بيوتيك ها ...

طور غيرمستقيم بر عملكرد ميكرو گليا تأثير جشم گيرى داشـته باشند؛ لذا بسيارى از اخـتلالات عصـبى از جمله بِاركينسـون، مالتييل اسكلروز، اوتيسم، اضطراب و حتى در مـواردى سكته مغزى نيز با فعاليت ميكرو گلياها، تركيب و توازن ميكروبيوتاى

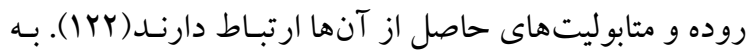
نظر مىرســ هـدف قرار دادن تركيـب ميكروبيو تـاى روده و همجينين القاى آنها جهت توليد متابوليتهاى مدنظر (از طريق مصرف محصـولات حـاوى تركيبـات بـرىبيوتيكك و يســبيوتيكك)، رويكردى نوين در بحث بيشخيرى و درمان مكملى

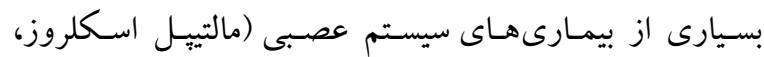

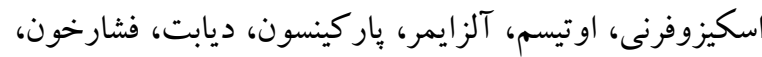
سكته مغزى) مطرح باشند.

\section{نتيجه كيرى}

مطالعه مرورى حاضـر، حيطه جديـدى از تحقيقـات در زمينه

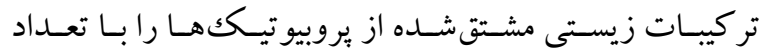
محسدودى از مقـالات در ايـن زمينـه مــنظـر قـرار داده اسـت. اطلاعات استخر اجده براى اين مطالعه از ·ب مقاله در راستاى اهداف مطالعه استخراج شده است. قابل ذكر اسـت كـه نتـايج

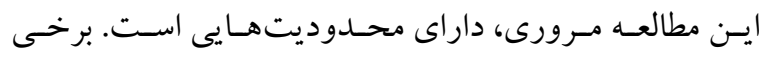

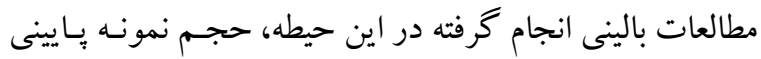
داشته و طول دوره مداخله نيز نسبتاً كو تاه بوده است. هم جنسين فاكتورهاى مختلفى ماننـد انواع روشهـاى غيرفعالسـازى و استخر اج، ماهيت دقيق بستبيو تيككهاى مصرفى، نوع سيستم حامل به كارگرفته شده و ميزان تلفشدگ مئ زيستى حين عبور

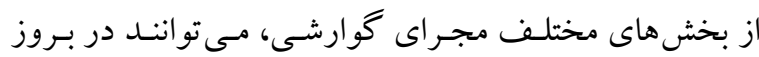
خو اص زيستى و سلامت بخشى آنها مؤثر واقع شوند؛ بنابر اين در مطالعات آتى تعيين دقيق فاكتورهاى مذكور جهت حصول اثرات سلامت بخش يستبيو تيككهاى مدنظر امـى ضـرورى

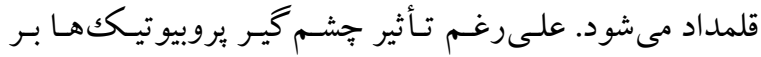

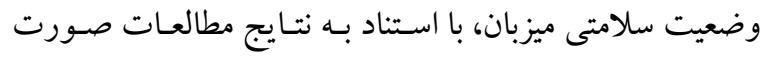

تواند عاملى مهم در تغييـر عملكـرد مغـز و رفتـار انسـان باشـــ. بسيارى از باكترىهاى مستقر در دستخاه گُوارشى ميزبان قـادر به توليـد مولكـولهـاى كـوجكى مانـــد دويـامين، إيىنفرين، نـورايىنفـرين، سـرتونين، اسـتيل كـولين و كابـا هستـند(IV)

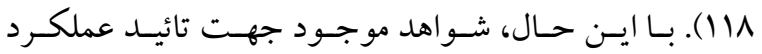
سيخنالينك عصبى اين تركيبات كافى نبوده و نيازمند مطالعات

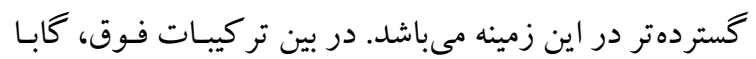
يكى از اساسىترين انتقال دهندههاى عصبى توليد شده توسط ميكروبيو تـا محسـوب مسى شـود و عملكـرد مهـارى بــر انتقـال

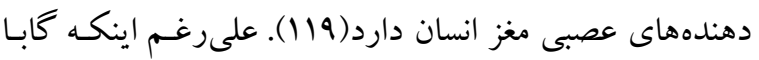
توليد شده توسط ميكروبيو تا قادر به عبور از سد خـون-مغـزى معرى

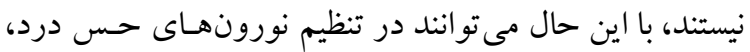

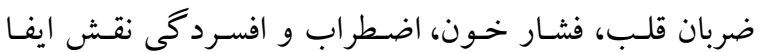
كنند( •r). قابل ذكر است كه هم اكنون گابا به عنوان يـك تركيب سـلامت بخـش در فرمو لاسيون غـذاهاى فراسـودمند

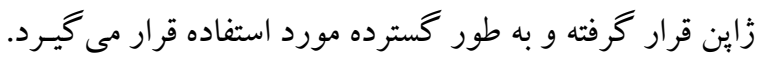
لاكتوياسيلوس برويس يتانسيل خـوبى جهـت توليـد تركيـب

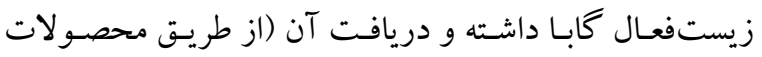
دارويى يا مكمل هاى غذايى) مى تواند موجـب سـلامت مغز و و

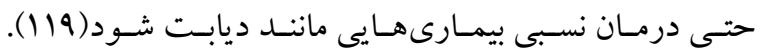

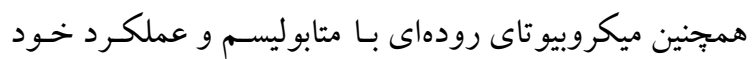
مى تو انند در ارتباط بـا بسـيارى از بيمـارىهـاى خـودايمنى و

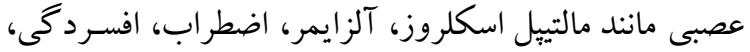

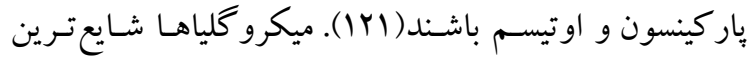

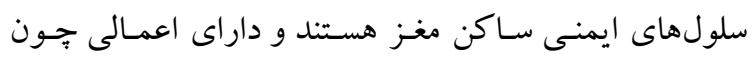

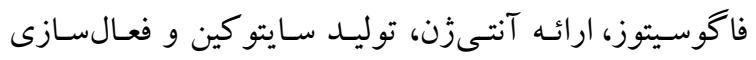

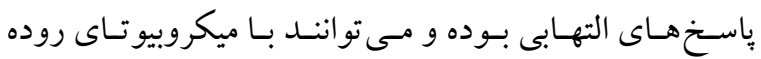

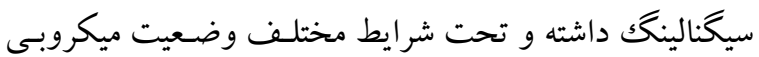
روده عملكردهاى مناسبى از خـود بـروز دهنـد. برخسى بسـت

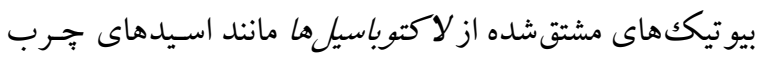
كو تاه زنجير (استات، يروبيونات و بوتيرات) نيز مى تواننـد بـهـ 
(يروبيو تيـككهــا) و برقــرارى شـــايط يوبيــوزيس و حفـــ

هومئوسـتازيس ميزبـان اسـت. در نتيجـه، مفـاهيم بروبيوتيكك، يرىبيو تيكك، سينبيو تيكك و بست بيو تيكك يـك رونــ هميشـه سبز هستند و مطالعات بيشـتر بـراى شناسـايى دقيـقتر و درك روابط بيجيجهد بين اين مفـاهيم ضـرورى بـه نظـر مسىرسـد كـه ممكن است به دركك مسير مكانيسم عمل آنهـا كمـك كنـد. يثزوهشهاى نوين امكان توليد اطلاعات دقيق براى اطمينـان از ثبات فرآيند توليد محصولات يستبيو تيكك و اثربخشى آنهـا را فــراهم مسىسـازد. عـلاوه بــر ايسن، مطالعـات مداخلـهاى و كار آزمايى بـالينى تصـادفى و نيـز مطالعـات متـابولوميكس بـه

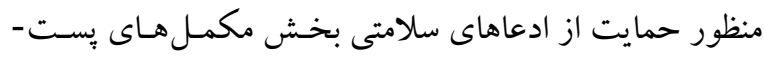
بيو تيكك مورد نياز هستند.

\section{تشكر و قدردانى}

نويسند گان مقاله حاضر اظهار مىدارند كه انتشار اين مقاله هيج گونه تضاد يا تعارض منافعى با افراد يا دستخاههاى خاصى ندارد. بدينوسيله از كميته تحقيقات دانشجويان دانشخاه علوم يزشكى تبريز تشكر و قدردانى مى گردد.

كر فته، تر كيبات بستبيو تيكك مى توانند در مقايسه با سلولهاى زنده يروبيو تيكك والـد خـود داراى مزيــتهـاى تكنولـوزيكىى، ايمنى و اقتصادى باشند. يستبيو تيككها داراى فعاليت زيستى بوده و مى توانند فعاليت ضـدالتهابى، تعـديل كننـدكى سيسـتم ايمنى، ضد اسهالى، ضد فشارخون، كاهندگى كلسترولســرم، متوقف ساختن تكثيـر سـلولى غيـر طبيعى و آنتى اكسـيدان را ايجاد كنند. اين خو اص نشان مىدهد كه يستبيو تيككها مسى توانند با ايجاد اثرات فيزيولـوزيكى خـاص بـه بهبـود سـلامت ميزبان كمكك كنند. حتى اكر مكانيسم عمل دقيق آنها به طور

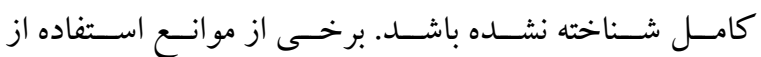

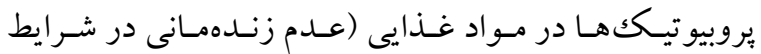
فر آورى، نخهدارى، توزيع و آماده سازى مواد غذايى) موجب مىشـود كـه يسـت بيو تيـك هـا يـك جـايخزين مناسـبى بـراى افزايش مدت زمان نكهدارى مواد غـذايى و بـا ارزش درمـانى مورد استفاده قرار كيرند. ذكر اين نكته حائز اهميت است كـه يستبيوتيككها نيز ماند تر كيبات برىبيو تيكك، به جاى افزودن كونه هاى جديد به ميكروبيوتاى روده، يروبيو تيككهاى موجود در دستخاه كوارش هر فرد را توسعه مسىدهنـد و ايـن بيـانكر

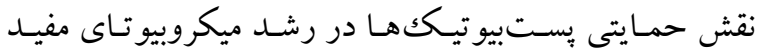

منابع 1. Abbasi A, Ghasempour Z, Sabahi S, Kafil HS, Hasannezhad P, Rahbar Saadat Y, et al. The biological activities of postbiotics in gastrointestinal disorders. Crit Rev Food Sci Nutr. 2021:122.

2. Kappel BA, De Angelis L, Heiser M,Ballanti M, Stoehr R, Goettsch C, et al. Cross-omics analysis revealed gut microbiome-related metabolic pathways underlying atherosclerosis development after antibiotics treatment. Mol Metab. 2020;36:100976.

3. Abbasi A, Aghebati-Maleki A, Yousefi M, Aghebati-Maleki L. Probiotic intervention as a potential therapeutic for managing gestational disorders and improving pregnancy outcomes. $\mathrm{J}$ Reprod Immunol. 2021;143:103244.

4. Wu H, Ma Y, Peng X, Qiu W, Kong L, Ren B, et al. Antibiotic-induced dysbiosis of the rat oral and gut microbiota and resistance to Salmonella. Arch Oral Biol. 2020;114:104730.

5. Strati F, Pujolassos M, Burrello C, Giuffrè MR, Lattanzi G, Caprioli F, et al. Antibioticassociated dysbiosis affects the ability of the gut microbiota to control intestinal inflammation upon fecal microbiota transplantation in experimental colitis models. Microbiome. 2021;9(1):115.

هجلم علمى دانشكاه علوه يِشكى كردستان / دوره بيست و شش / دهر و آبان م。ع|| 
6. Tannock GW, Savage DC. Influences of dietary and environmental stress on microbial populations in the murine gastrointestinal tract. Infect Immun. 1974;9(3):591-598.

7. Nabavi S, Rafraf M, Somi MH, Homayouni-Rad A, Asghari-Jafarabadi M. The effects of probiotic yogurt on metabolic factors in nonalcoholic fatty liver disease. SJKU. 2016;20(6):1225.

8. Marzorati M, Abbeele PVd, Bubeck SS, Bayne T, Krishnan K, Young A, et al. Bacillus subtilis HU58 and Bacillus coagulans SC208 Probiotics Reduced the Effects of AntibioticInduced Gut Microbiome Dysbiosis in an M-SHIME ${ }^{\circledR}$ Model. Microorganisms. 2020;8(7):1028.

9. Hoffman JB, Petriello MC, Morris AJ, Mottaleb MA, Sui Y, Zhou C, et al. Prebiotic inulin consumption reduces dioxin-like PCB 126-mediated hepatotoxicity and gut dysbiosis in hyperlipidemic Ldlr deficient mice. Environ Pollut. 2020;261:114183.

10. Kim C-S, Cha L, Sim M, Jung S, Chun WY, Baik HW, et al. Probiotic Supplementation Improves Cognitive Function and Mood with Changes in Gut Microbiota in CommunityDwelling Older Adults: A Randomized, Double-Blind, Placebo-Controlled, Multicenter Trial. J Gerontol A Biol Sci Med Sci. 2021;76(1):32-40.

11. Zhao W, Liu Y, Kwok L-Y, Cai T, Zhang W. The immune regulatory role of Lactobacillus acidophilus: An updated meta-analysis of randomized controlled trials. Food Biosci. 2020:100656.

12. Lee CH, Choi Y, Seo SY, Kim S-H, Kim IH, Kim SW, et al. Addition of probiotics to antibiotics improves the clinical course of pneumonia in young people without comorbidities: a randomized controlled trial. Sci Rep. 2021;11(1):1-9.

13. Sanders ME. How do we know when something called "probiotic" is really a probiotic? A guideline for consumers and health care professionals. Funct Food Rev. 2009;1(1):3-12.

14. Mohamadshahi M, Veissi M, Haidari F, Shahbazian H, Kaydani G-A, Mohammadi F. Effects of probiotic yogurt consumption on inflammatory biomarkers in patients with type 2 diabetes. BioImpacts. 2014;4(2):83.

15. Homayouni Rad A, Aghebati Maleki L, Samadi Kafil H, Abbasi A. Postbiotics :A novel strategy in food allergy treatment. Crit Rev Food Sci Nutr. 2020:1-8.

16. Rad AH, Maleki LA, Kafil HS, Zavoshti HF, Abbasi A. Postbiotics as novel healthpromoting ingredients in functional foods. Health Promot Perspect. 2020;10(1):3-4.

17. Lee JW, Shin JG, Kim EH, Kang HE, Yim IB, Kim JY, et al. Immunomodulatory and antitumor effects in vivo by the cytoplasmic fraction of Lactobacillus casei and Bifidobacterium longum. J Vet Res. 2004;5(1):41-8.

18. Raman M, Ambalam P, Doble M. Probiotics and bioactive carbohydrates in colon cancer management. $1^{\text {st }}$ ed. India:Springer, 2016.

19. Abbasi A, Sheykhsaran E, Kafil HS. Postbiotics: Science, Technology and Applications. $1^{\text {st }}$ ed. United Arab Emirates:Bentham Science Publishers, 2021.

20. Abbasi A, Aghebati-Maleki L, Homayouni-Rad A. The promising biological role of postbiotics derived from probiotic Lactobacillus species in reproductive health. Crit Rev Food Sci Nutr. 2021:1-3.

21. Liong M-T. Safety of probiotics: translocation and infection. Nutr Rev. 2008;66(4):192-202.

22. Abriouel H, Muñoz MdCC, Lerma LL, Montoro BP, Bockelmann W, Pichner R, et al. New insights in antibiotic resistance of Lactobacillus species from fermented foods. Food Res Int. 2015;78:465-81. 


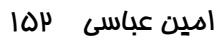

23. Kim MJ, Ku S, Kim SY, Lee HH, Jin H, Kang S, et al. Safety Evaluations of Bifidobacterium bifidum BGN4 and Bifidobacterium longum BORI. Int $\mathrm{J}$ Mol Sci. 2018;19(5):1422.

24. Homayouni rad A, Fathi-zavoshti H, Douroud N, Shahbazi N, Abbasi A. Evaluating the Role of Postbiotics as a New Generation of Probiotics in Health and Diseases. arumsj. 2020;19(4):381-99.

25. Rad A, Abbasi A, Javadi A, Pourjafar H, Javadi M, Khaleghi M. Comparing the microbial quality of traditional and industrial yoghurts. Biointerface Res Appl Chem. 2020;10(4):6020-5.

26. Taverniti V, Guglielmetti S. The immunomodulatory properties of probiotic microorganisms beyond their viability (ghost probiotics: proposal of paraprobiotic concept). Genes Nutr. 2011;6(3):261-74.

27. Karimi N, Jabbari V, Nazemi A, Ganbarov K, Karimi N, Tanomand A, Karimi S, Abbasi A, Yousefi B, Khodadadi E. Thymol, cardamom and Lactobacillus plantarum nanoparticles as a functional candy with high protection against Streptococcus mutans and tooth decay. Microb Pathog. 2020:104481.

28. Mohan A, Hadi J, Gutierrez-Maddox N, Li Y, Leung IK, Gao Y, Shu Q, Quek SY. Sensory, Microbiological and Physicochemical Characterisation of Functional Manuka Honey Yogurts Containing Probiotic Lactobacillus reuteri DPC16. Foods. 2020;9(1):106.

29. Rad AH, Akbarzadeh F, Mehrabany EV. Which are more important: Prebiotics or probiotics? Nutrition. 2012;28(11/12):1196.

30. Homayouni A, Azizi A, Ehsani M, Yarmand M, Razavi S. Effect of microencapsulation and resistant starch on the probiotic survival and sensory properties of synbiotic ice cream. Food Chem. 2008;111(1):50-5.

31. de Almada CN, Almada CN, Martinez RC, Sant'Ana AS. Paraprobiotics: evidences on their ability to modify biological responses, inactivation methods and perspectives on their application in foods. Trends Food Sci Technol. 2016;58:96-114.

32. Rad A, Abbasi A, Kafil H, Ganbarov K. Potential Pharmaceutical and Food Applications of Postbiotics: A review. Curr Pharm Biotechnol. 2020;21(15):1576-1587.

33. Cicenia A, Santangelo F, Gambardella L, Pallotta L, Iebba V, Scirocco A, et al. Protective role of postbiotic mediators secreted by Lactobacillus rhamnosus GG versus lipopolysaccharideinduced damage in human colonic smooth muscle cells. J Clin Gastroenterol. 2016;50:S140-4.

34. Konstantinov SR, Kuipers EJ, Peppelenbosch MP. Functional genomic analyses of the gut microbiota for CRC screening. Nat Rev Gastroenterol Hepatol. 2013;10(12):741.

35. Sharma M, Shukla G. Metabiotics: one step ahead of probiotics; an insight into mechanisms involved in anticancerous effect in colorectal cancer. Front Microbiol. 2016;7:1940.

36. Sánchez B, Ruiz L, Gueimonde M, Ruas-Madiedo P, Margolles A. Toward improving technological and functional properties of probiotics in foods. Trends Food Sci Technol. 2012;26(1):56-63.

37. Hibbing ME, Fuqua C, Parsek MR, Peterson SB. Bacterial competition: surviving and thriving in the microbial jungle. Nat Rev Microbiol. 2010;8(1):15.

38. Chua KJ,Kwok WC, Aggarwal N, Sun T, Chang MW. Designer probiotics for the prevention and treatment of human diseases. Curr Opin Chem Biol. 2017;40:8-16.

39. Nakamura F, Ishida Y, Sawada D, Ashida N, Sugawara T, Sakai M, et al. Fragmented lactic Acid bacterial cells activate peroxisome proliferator-activated receptors and ameliorate Dyslipidemia in obese mice. J Agric Food Chem. 2016;64(12):2549-59.

هبله علمى دانشكاه علوم دِزشكى كردستان / دوره بيست و شش / دعر و آبان معان 


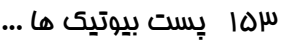

40. Tejada-Simon MV, Pestka JJ. Proinflammatory cytokine and nitric oxide induction in murine macrophages by cell wall and cytoplasmic extracts of lactic acid bacteria. J Food Prot. 1999;62(12):1435-44.

41. Sokol H, Pigneur B, Watterlot L, Lakhdari O, Bermúdez-Humarán LG, Gratadoux J-J, et al. Faecalibacterium prausnitzii is an anti-inflammatory commensal bacterium identified by gut microbiota analysis of Crohn disease patients. Proc Natl Acad Sci. 2008;105(43):16731-6.

42. Vidal K, Donnet-Hughes A, Granato D. Lipoteichoic acids from Lactobacillus johnsonii strain La1 and Lactobacillus acidophilus strain La10 antagonize the responsiveness of human intestinal epithelial HT29 cells to lipopolysaccharide and gram-negative bacteria. Infect Immun. 2002;70(4):2057-64.

43. Mileti E, Matteoli G, Iliev ID, Rescigno M. Comparison of the immunomodulatory properties of three probiotic strains of Lactobacilli using complex culture systems: prediction for in vivo efficacy. PloS one. 2009;4(9):e7056.

44. Tsilingiri K, Barbosa T, Penna G, Caprioli F, Sonzogni A, Viale G, et al. Probiotic and postbiotic activity in health and disease: comparison on a novel polarised ex-vivo organ culture model. Gut. 2012;61(7):1007-15.

45. Choi S, Kim Y, Han K, You S, Oh S, Kim SH. Effects of Lactobacillus strains on cancer cell proliferation and oxidative stress in vitro. Lett Appl Microbiol. 2006;42(5):452-8.

46. Tiptiri-Kourpeti A, Spyridopoulou K, Santarmaki V, Aindelis G, Tompoulidou E, Lamprianidou EE, et al. Lactobacillus casei exerts anti-proliferative effects accompanied by apoptotic cell death and up-regulation of TRAIL in colon carcinoma cells. PloS one. 2016;11(2):e0147960.

47. Ou C, Ko J, Lin M. Antioxidative effects of intracellular extracts of yogurt bacteria on lipid peroxidation and intestine 407 cells. J Food Drug Anal. 2006;14(3):304-10.

48. Kim H, Chae H, Jeong S, Ham J, Im S, Ahn C, et al. In vitro antioxidative properties of lactobacilli. Asian-Australas J Anim Sci. 2005;19(2):262-5.

49. Zhang S, Liu L, Su Y, Li H, Sun Q, Liang X, et al. Antioxidative activity of lactic acid bacteria in yogurt. Afr J Microbiol Res. 2011;5(29):5194-201.

50. Amaretti A, Di Nunzio M, Pompei A, Raimondi S, Rossi M, Bordoni A. Antioxidant properties of potentially probiotic bacteria: in vitro and in vivo activities. Appl Microbiol Biotechnol. 2013;97(2):809-17.

51. Shin HS, Park SY, Lee DK, Kim SA, An HM, Kim JR, et al. Hypocholesterolemic effect of sonication-killed Bifidobacterium longum isolated from healthy adult Koreans in high cholesterol fed rats. Arch Pharm Res. 2010;33(9):1425-31.

52. Sawada H, Furushiro M, Hirai K, Motoike M, Watanabe T, Yokokura T. Purification and Characterization of an Antihypertensive Compound from Lactohacillus casei. Agric Biol Chem. 1990;54(12):3211-9.

53. Dinić M, Lukić J, Djokić J, Milenković M, Strahinić I, Golić N, et al. Lactobacillus fermentum postbiotic-induced autophagy as potential approach for treatment of acetaminophen hepatotoxicity. Front Microbiol. 2017;8:594.

54. Sharma S, Singh R, Kakkar P. Modulation of Bax/Bcl-2 and caspases by probiotics during acetaminophen induced apoptosis in primary hepatocytes. Food Chem Toxicol. 2011;49(4):7709. 
اهين عباسى عاسما

55. Kareem KY, Ling FH, Chwen LT, Foong OM, Asmara SA. Inhibitory activity of postbiotic produced by strains of Lactobacillus plantarum using reconstituted media supplemented with inulin. Gut Pathog. 2014;6(1):1-7.

56. Kim HG, Lee SY,Kim NR, Lee HY, Ko MY, Jung BJ, et al. Lactobacillus plantarum lipoteichoic acid down-regulated Shigella flexneri peptidoglycan-induced inflammation. Mol Immunol. 2011;48(4):382-91.

57. Matsuguchi T, Takagi A, Matsuzaki T, Nagaoka M, Ishikawa K,Yokokura T, et al. Lipoteichoic acids from Lactobacillus strains elicit strong tumor necrosis factor alpha-inducing activities in macrophages through Toll-like receptor 2. Clin Diagn Lab Immunol. 2003;10(2):259-66.

58. Jensen GS ,Benson KF, Carter SG, Endres JR. GanedenBC 30TM cell wall and metabolites: anti-inflammatory and immune modulating effects in vitro. BMC Immunol. 2010;11(1):1-14.

59. Nozari S, Faridvand Y, Etesami A, Ahmad Khan Beiki M, Miresmaeili Mazrakhondi SA, Abdolalizadeh J. Potential anticancer effects of cell wall protein fractions from Lactobacillus paracasei on human intestinal Caco-2 cell line. Lett Appl Microbio. 2019;69(3):148-54.

60. Chen D, Jin D, Huang S, Wu J, Xu M, Liu T, et al. Clostridium butyricum, a butyrateproducing probiotic, inhibits intestinal tumor development through modulating Wnt signaling and gut microbiota. Cancer Lett. 2020;469:456-67.

61. Konishi H, Fujiya M, Tanaka H, Ueno N, Moriichi K, Sasajima J, et al. Probiotic-derived ferrichrome inhibits colon cancer progression via JNK-mediated apoptosis. Nat Commun. 2016;7(1):1-12.

62. Shigwedha N, Sichel L, Jia L, Zhang L. Probiotical Cell Fragments (PCFs) as "Novel Nutraceutical Ingredients". J Biosci Med. 2014;2(03):43.

63. Shenderov BA. Metabiotics: novel idea or natural development of probiotic conception. Microb Ecol Health Dis. 2013;24(1):20399.

64. Abbasi A, Hajipour N, Hasannezhad P, Baghbanzadeh A, Aghebati-Maleki L. Potential in vivo delivery routes of postbiotics. Crit Rev Food Sci Nutr. 2020:1-39.

65. Homayouni Rad A, Aghebati Maleki L, Samadi Kafil H, Fathi Zavoshti H, Abbasi A. Postbiotics as Promising Tools for Cancer Adjuvant Therapy. Adv Pharm Bull. 2021;11(1):1-5.

66. Homayouni-rad A, Oroojzadeh P, Abbasi A. The Effect of Yeast Kluyveromyces marxianus as a Probiotic on the Microbiological and Sensorial Properties of Set Yoghurt during Refrigerated Storage. JAUMS. 2021;20(2):254-68.

67. Doron S, Snydman DR. Risk and safety of probiotics. Clin Infect Dis. 2015;60(2):S129-S34.

68. Haileselassie Y, Navis M, Vu N, Qazi KR, Rethi B, Sverremark-Ekström E. Postbiotic modulation of retinoic acid imprinted mucosal-like dendritic cells by probiotic Lactobacillus reuteri 17938 in vitro. Front Immunol. 2016;7:96.

69. Gao J, Li Y, Wan Y, Hu T, Liu L, Yang S, et al. A novel postbiotic from Lactobacillus rhamnosus GG with a beneficial effect on intestinal barrier function. Front Microbiol. 2019;10:477.

70. Malagón-Rojas JN, Mantziari A. Postbiotics for Preventing and Treating Common Infectious Diseases in Children: A Systematic Review. Nutrients. 2020;12(2):389.

71. Izuddin WI, Loh TC, Samsudin AA, Foo HL. In vitro study of postbiotics from Lactobacillus plantarum RG14 on rumen fermentation and microbial population. Rev Bras Zootec. 2018;47.

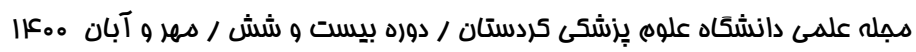


72. Dunand E, Burns P, Binetti A, Bergamini C, Peralta GH, Forzani L, et al .Postbiotics produced at laboratory and industrial level as potential functional food ingredients with the capacity to protect mice against Salmonella infection. J Appl Microbiol. 2019;127(1):219-29.

73. Kok MG, Ruijken MM, Swann JR, Wilson ID, Somsen GW, de Jong GJ. Anionic metabolic profiling of urine from antibiotic-treated rats by capillary electrophoresis-mass spectrometry. Anal Bioanal Chem. 2013;405(8):2585-94.

74. Moradi M, Molaei R, Guimarães JT. A review on preparation and chemical analysis of postbiotics from lactic acid bacteria. Enzyme Microb Technol. 2021;143:109722.

75. Homayouni Rad A, Samadi Kafil H, Fathi Zavoshti H, Shahbazi N, Abbasi A. Therapeutically Effects of Functional Postbiotic Foods. Clin Excell. 2020;10(2):33-52.

76. Ogawa A, Kadooka Y, Kato K, Shirouchi B, Sato M. Lactobacillus gasseri SBT2055 reduces postprandial and fasting serum non-esterified fatty acid levels in Japanese hypertriacylglycerolemic subjects. Lipids Health Dis. 2014;13(1):36.

77. den Besten G, van Eunen K, Groen AK, Venema K, Reijngoud D-J, Bakker BM. The role of short-chain fatty acids in the interplay between diet, gut microbiota, and host energy metabolism. J Lipid Res. 2013;54(9):2325-40.

78. Chi W, Dao D, Lau TC, Henriksbo BD, Cavallari JF, Foley KP, et al. Bacterial peptidoglycan stimulates adipocyte lipolysis via NOD1. PLoS One. 2014;9(5):e97675.

79. Cavallari JF, Fullerton MD, Duggan BM, Foley KP, Denou E, Smith BK, et al .Muramyl dipeptide-based postbiotics mitigate obesity-induced insulin resistance via IRF4. Cell Metabol. 2017;25(5):1063-74. e3.

80. Escamilla J, Lane MA, Maitin V. Cell-free supernatants from probiotic Lactobacillus casei and Lactobacillus rhamnosus GG decrease colon cancer cell invasion in vitro. Nutr Cancer. 2012;64(6):871-8.

81. Kareem KY, Ling FH, Chwen LT, Foong OM, Asmara SA. Inhibitory activity of postbiotic produced by strains of Lactobacillus plantarum using reconstituted media supplemented with inulin. Gut Pathog. 2014;6(1):23.

82. Imperial IC, Ibana JA. Addressing the antibiotic resistance problem with probiotics: reducing the risk of its double-edged sword effect. Front Microbiol. 2016;7:1983.

83. Aguilar-Toalá J, Garcia-Varela R, Garcia H, Mata-Haro V, González-Córdova A, VallejoCordoba B, et al. Postbiotics: An evolving term within the functional foods field. Trends Food Sci Technol. 2018;75:105-14.

84. Weese JS, Martin H. Assessment of commercial probiotic bacterial contents and label accuracy. Can Vet J. 2011;52(1):43.

85. Palacios MC, Haros M, Sanz Y, Rosell CM. Selection of lactic acid bacteria with high phytate degrading activity for application in whole wheat breadmaking. LWT. 2008;41(1):82-92.

86. Haros M, Bielecka M, Honke J, Sanz Y. Phytate-degrading activity in lactic acid bacteria. Pol J Food Nutr Sci. 2008;58(1).

87. Ahmad Rather I, Seo B, Rejish Kumar V, Choi UH, Choi KH, Lim J, et al. Isolation and characterization of a proteinaceous antifungal compound from L actobacillus plantarum YML 007 and its application as a food preservative. Lett Appl Microbiol. 2013;57(1):69-76.

88. Torino MI, Font de Valdez G, Mozzi F. Biopolymers from lactic acid bacteria. Novel applications in foods and beverages. Front Microbiol. 2015;6:834.

89. And HC, Hoover D. Bacteriocins and their food applications. Compr Rev Food Sci Food Saf. 2003;2(3):82-100. 
اهين عباسى

90. Yu H-S, Lee N-k, Choi A-j, Choe J-s, Bae CH, Paik H-D. Anti-Inflammatory Potential of Probiotic Strain Weissella cibaria JW15 Isolated from Kimchi through Regulation of NF- $\mathrm{B}$ and MAPKs Pathways in LPS-Induced RAW 264.7 Cells. J Microbiol Biotechnol. 2019;29(7):102232.

91. López-Fandiño R. Role of dietary lipids in food allergy. Crit Rev Food Sci Nutr. 2019:1-18.

92. Paparo L, Nocerino R, Di Scala C, Della Gatta G, Di Costanzo M, Buono A, et al .Targeting Food Allergy with Probiotics. Probiotics and Child Gastrointestinal Health. Adv Exp Med Biol. 2019;1125:57-68.

93. Gupta RS, Springston EE, Warrier MR, Smith B, Kumar R, Pongracic J, et al. The prevalence, severity, and distribution of childhood food allergy in the United States. Pediatrics. 2011;128(1):e9-e17.

94. Prince BT, Mandel MJ, Nadeau K, Singh AM. Gut microbiome and the development of food allergy and allergic disease. Pediatr Clin. 2015;62(6):1479-92.

95. Nowak-Węgrzyn A, Chatchatee P. Mechanisms of tolerance induction. Ann Nutr Metab. 2017;70(2):7-24.

96. Gill P, Van Zelm M, Muir J, Gibson P. Short chain fatty acids as potential therapeutic agents in human gastrointestinal and inflammatory disorders. Aliment Pharmacol Ther. 2018;48(1):1534.

97. Oak SJ, Jha R. The effects of probiotics in lactose intolerance: a systematic review. Crit Rev Food Sci Nutr. 2019;59(11):1675-1683.

98. Rampengan NH, Manoppo J, Warouw SM. Comparison of efficacies between live and killed probiotics in children with lactose malabsorption. Southeast Asian J Trop Med Public Health. 2010;41(2):474-81.

99. Klein G, Schanstra JP, Hoffmann J, Mischak H, Siwy J, Zimmermann K. Proteomics as a Quality Control Tool of Pharmaceutical Probiotic Bacterial Lysate Products. PloS one. 2013;8(6):e66682-e.

100. Zihler A, Le Blay G, De Wouters T, Lacroix C, Braegger CP, Lehner A, et al. In vitro inhibition activity of different bacteriocin-producing Escherichia coli against Salmonella strains isolated from clinical cases. Lett Appl Microbiol. 2009;49(1):31-8.

101. Shortening of the period of fecal excretion of salmonella in infants under treatment with hylak forte. Paediatr Paedol. 1991;26(2):111-4.

102. Ray S, Sherlock A, Wilken T, Woods T. Cell wall lysed probiotic tincture decreases immune response to pathogenic enteric bacteria and improves symptoms in autistic and immune compromised children. Explore. 2010;19(1):1-5.

103. Kober M-M, Bowe WP. The effect of probiotics on immune regulation, acne, and photoaging. Int J Womens Dermatol. 2015;1(2):85-9.

104. Suchodolski JS, Jergens AE. Recent advances and understanding of using probiotic-based interventions to restore homeostasis of the microbiome for the prevention/therapy of bacterial diseases. Virulence Mech Bact Pathog. 2016:823-41.

105. Piqué N, Berlanga M, Miñana-Galbis D. Health benefits of heat-killed (Tyndallized) probiotics: An overview. Int J Mol Sci. 2019;20(10):2534.

106. Chuang L, Wu K-G, Pai C, Hsieh P-S, Tsai J-J, Yen J-H, et al. Heat-killed cells of lactobacilli skew the immune response toward $\mathrm{T}$ helper 1 polarization in mouse splenocytes and dendritic cell-treated T cells. J Agric Food Chem. 2007;55(26):11080-6.

هجلم علمى دانشكاه علوه يِشكى كردستان / دوره بيست و شش / دهر و آبان م。ع|| 


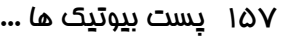

107. Ou CC, Lin SL, Tsai JJ, Lin MY. Heat-killed lactic acid bacteria enhance immunomodulatory potential by skewing the immune response toward Th1 polarization. J Food Sci. 2011;76(5):M260-M7.

108. Schwendicke F, Horb K, Kneist S, Dörfer C, Paris S. Effects of heat-inactivated Bifidobacterium BB12 on cariogenicity of Streptococcus mutans in vitro. Arch Oral Biol. 2014;59(12):1384-90.

109. Kawase M, He F, Miyazawa K, Kubota A, Yoda K, Hiramatsu M. Orally administered heatkilled Lactobacillus gasseri TMC0356 can upregulate cell-mediated immunity in senescenceaccelerated mice. FEMS Microbiol Lett. 2012;326(2):125-30.

110. Anwar F, Altayb HN, Al-Abbasi FA, Al-Malki AL, Kamal MA, Kumar V. Antiviral Effects of Probiotic metabolites on COVID-19. J Biomol Struct Dyn. 2020(just-accepted):1-11.

111. Rad AH, Aghebati-Maleki L, Kafil HS, Abbasi A. Molecular mechanisms of postbiotics in colorectal cancer prevention and treatment. Crit Rev Food Sci Nutr. 2020:1-17.

112. Zagouri F, Korakiti A-M, Zakopoulou R, Kyriazoglou A, Zografos E, Haidopoulos D, et al. Taxanes during pregnancy in cervical cancer: A systematic review and pooled analysis. Cancer Treat Rev. 2019;79:101885.

113. Kyrochristos ID, Roukos DH. Comprehensive intra-individual genomic and transcriptional heterogeneity: Evidence-based Colorectal Cancer Precision Medicine. Cancer Treat Rev. 2019:101894.

114. Oruç Z, Kaplan MA. Effect of exercise on colorectal cancer prevention and treatment. World J Gastrointest Oncol. 2019;11(5):348.

115. Österlund P, Ruotsalainen T, Korpela R, Saxelin M, Ollus A, Valta P, et al. Lactobacillus supplementation for diarrhoea related to chemotherapy of colorectal cancer: a randomised study. Br J Cancer Suppl. 2007;97(8):1028-34.

116. Tiptiri-Kourpeti A, Spyridopoulou K, Santarmaki V, Aindelis G, Tompoulidou E, Lamprianidou EE, et al. Lactobacillus casei exerts anti-proliferative effects accompanied by apoptotic cell death and up-regulation of TRAIL in colon carcinoma cells. PloS one. 2016;11(2):e0147960.

117. Norris V, Molina F, Gewirtz AT. Hypothesis: bacteria control host appetites. J Bacteriol. 2013;195(3):411-6.

118. Mittal R, Debs LH, Patel AP, Nguyen D, Patel K, O'Connor G, et al. Neurotransmitters: The critical modulators regulating gut-brain axis. J Cell Physiol. 2017;232(9):2359-72.

119. Dinan TG, Cryan JF. Microbes, immunity, and behavior: psychoneuroimmunology meets the microbiome. Neuropsychopharmacol. 2017;42(1):178-92.

120. Hyland NP, Cryan JF. Microbe-host interactions: Influence of the gut microbiota on the enteric nervous system. Dev Biol. 2016;417(2):182-7.

121. Moos WH, Faller DV, Harpp DN, Kanara I, Pernokas J, Powers WR, et al. Microbiota and neurological disorders: a gut feeling. Biores Open Access. 2016;5(1):137 $\leqslant 0,-$

122. Erny D, Hrabě de Angelis AL, Prinz M. Communicating systems in the body: how microbiota and microglia cooperate. Immunology. 2017;150(1):7-15. 